\title{
An integrated modeling study on the effects of mineral dust and sea salt particles on clouds and precipitation
}

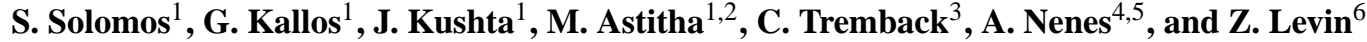 \\ ${ }^{1}$ University of Athens, School of Physics, University of Athens Campus, Bldg. Phys-5, 15784 Athens, Greece \\ ${ }^{2}$ Energy, Environment and Water Research Centre, The Cyprus Institute, Nicosia, Cyprus, Greece \\ ${ }^{3}$ ATMET LLC P.O. Box 19195, Boulder, CO 80308-2195, USA \\ ${ }^{4}$ School of Chemical and Biomolecular Engineering, Georgia Institute of Technology, USA \\ ${ }^{5}$ School of Earth and Atmospheric Sciences, Georgia Institute of Technology, USA \\ ${ }^{6}$ Dept. of Geophysics and Planetary Sciences, Tel Aviv University, Tel Aviv, Israel
}

Received: 24 August 2010 - Published in Atmos. Chem. Phys. Discuss.: 14 October 2010

Revised: 23 December 2010 - Accepted: 24 January 2011 - Published: 31 January 2011

\begin{abstract}
This report addresses the effects of pollution on the development of precipitation in clean ("pristine") and polluted ("hazy") environments in the Eastern Mediterranean by using the Integrated Community Limited Area Modeling System (ICLAMS) (an extended version of the Regional Atmospheric Modeling System, RAMS). The use of this model allows one to investigate the interactions of the aerosols with cloud development. The simulations show that the onset of precipitation in hazy clouds is delayed compared to pristine conditions. Adding small concentrations of GCCN to polluted clouds promotes early-stage rain. The addition of GCCN to pristine clouds has no effect on precipitation amounts. Topography was found to be more important for the distribution of precipitation than aerosol properties. Increasing by $15 \%$ the concentration of hygroscopic dust particles for a case study over the Eastern Mediterranean resulted in more vigorous convection and more intense updrafts. The clouds that were formed extended about three kilometers higher, delaying the initiation of precipitation by one hour. Prognostic treatment of the aerosol concentrations in the explicit cloud droplet nucleation scheme of the model, improved the model performance for the twenty-four hour accumulated precipitation. The spatial distribution and the amounts of precipitation were found to vary greatly between the different aerosol scenarios. These results indicate the large uncertainty that remains and the need for more accurate description of aerosol feedbacks in atmospheric models and climate change predictions.
\end{abstract}

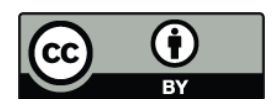

Correspondence to: G. Kallos (kallos@mg.uoa.gr)

\section{Introduction}

Aerosols are a mixture of natural and anthropogenic particles. Mineral dust, sea-salt, primary biogenic particles and volcanic ash originate from natural sources, while anthropogenic particles originate from industrial activity, fossilfuel and biomass burning. Aerosol particles directly affect the radiation budget of the atmosphere by absorbing and/or scattering radiation across the solar and long-wave radiation spectrum (Charlson et al., 1992; IPCC, 2007; Myhre et al., 2003; Seinfeld et al., 2004; Ramanathan et al., 2007). Additionally, they influence the nutrient dynamics and biogeochemical cycling of both terrestrial and oceanic ecosystems and may have considerable impacts on human health (Dockery and Pope, 1994; Herut et al., 2002; Meskhidze et al., 2003, 2005; Meskhidze and Nenes, 2006; Mahowald et al., 2008; Mitsakou et al., 2008). Airborne particles serve as cloud condensation nuclei (CCN) and ice nuclei (IN); changes thereof can affect the cloud cover, radiative properties, the distribution of precipitation and the hydrological cycle in general (Twomey et al., 1977; Albrecht, 1989; De Mott et al., 2003; Sassen et al., 2003; Andreae and Rosenfeld, 2008). Quantifying the number of particles that act as $\mathrm{CCN}$, as well as the number of particles that can initiate heterogeneous ice formation processes (ice nuclei, IN) is essential for determining the role of aerosols in cloud and precipitation processes (e.g., Lohmann and Feichter, 2005; Levin and Cotton, 2009). Moreover, formation of secondary particles and atmospheric ageing of aerosol lead to particles with substantially different properties than those at source regions (Seinfeld and Pandis, 1998; Levin et al., 1996; Wurzler at al., 2000; Jacobson, 2001; Chung and Seinfeld, 2002).

Published by Copernicus Publications on behalf of the European Geosciences Union. 
Mineral dust and sea salt are major components of particulate matter in the atmosphere. Desert dust accounts for more than $50 \%$ of the global aerosol load (Andreae et al., 1986; Zender et al., 2004) and the long range transport of dust particles can influence the composition and dynamic state of the atmosphere thousands of kilometers downwind of their source region (Kallos et al., 2007). Under favourable conditions, dust particles originating from Northern and Central Africa may be elevated and travel towards the Atlantic and Caribbean (Karyampudi, 1979; Karyampudi et al., 1999; Prospero et al., 2005; Kallos et al., 2006) or cross the Mediterranean towards Europe affecting both air quality and meteorology in Southern Europe (Mitsakou et al., 2008; Querol et al., 2009). Also Saharan dust radiative effects have a significant impact on the Asian monsoon (Lau et al., 2006; Lau and Kim, 2006) and on the West African monsoon and Atlantic climate (Lau et al., 2009; Sun et al., 2009). Dust particles are known to be efficient ice nuclei (IN) and contribute to the formation of ice crystals in high clouds (DeMott et al., 2003a; Teller and Levin, 2006). During their transport in the atmosphere the dust particles interact with sea salt or anthropogenic pollutants, mainly sulfates and nitrates, and form internally mixed particles, consisting of a core of mineral dust with coatings of soluble material (Levin et al., 1996). The soluble coating on the dust particles converts them into efficient $\mathrm{CCN}$ while maintaining their ability as IN (Levin et al., 2006; Astitha and Kallos, 2008; Astitha et al., 2010). Sea- salt particles are also very efficient CCN and is the dominant source of particulate matter in the marine boundary layer (Gong at al., 2002; Pierce and Adams, 2006).

The amount of particles that can act as $\mathrm{CCN}$ and nucleate cloud droplets depends on the concentration of available particles, their size distribution and their chemical composition (e.g., Köhler, 1936; Charlson et al., 2001; Nenes et al., 2002). Additionally, absorption of solar radiation by dust, results in heating of the dust layer and subsequently in modification of the thermodynamic and dynamical structure of the atmosphere, thus leading to suppression or enhancement of precipitation depending on the type of the clouds (Yin and Chen, 2007; Lau et al., 2009; Wilcox et al., 2010). The interplay between cloud dynamics and the composition of the atmosphere may delay the initiation of precipitation or steer a storm towards a different location and precipitation amounts will vary accordingly (Lynn et al., 2005b; van den Heever and Cotton, 2007; Rosenfeld at al., 2007; Zhang et al., 2007; Cotton et al., 2007).

By modifying the microphysical, optical and radiative properties of clouds, dust and salt particles contribute to the indirect aerosol effect and introduce significant uncertainty in assessing the anthropogenic impact on climate change (Charlson et al., 1990; Lohmann and Feichter, 2005; IPCC, 2007; Andreae and Rosenfeld, 2008). The effects of dust and sea salt on regional climate depend also on the local topography, soil characteristics (e.g., Junkermann et al., 2009) and cloud type (Seifert and Beheng, 2006). Therefore, the effects of atmospheric composition on clouds and precipitation are not monotonic and may differ from one area to another.

The complexity of the above processes and the possible interactions and feedbacks across all scales in the climate system, indicate the need for an integrated approach (Stevens and Feingold, 2009). The main objectives of the paper are to : (1) Describe the new RAMS/ICLAMS model development, (2) Perform sensitivity and evaluation tests for various model elements, (3) Perform a full model analysis of a case study where adequate data sets were available, (4) Test the effects of natural aerosols on clouds and precipitation. A brief description of the new model developments is presented in Sect. 2. Section 3 includes idealized sensitivity tests as well as the analysis of an experimental case. Finally the main results are summarized in Sect. 4.

\section{Description of ICLAMS}

The Regional Atmospheric Modeling System (RAMSv6) (Pielke et al., 1992; Cotton et al., 2003) was the basis for developing the Integrated Community Limited Area Modeling System (ICLAMS) used in this study. This new version of the model has been designed for air pollution and climate research applications and includes several new capabilities related to physical and chemical processes in the atmosphere. The model components are summarised in Table 1; new developments include an interactive desert-dust and sea-salt module, biogenic and anthropogenic pollutants parameterization, gas/cloud/aerosol chemistry, explicit cloud droplet nucleation scheme and an improved radiative transfer scheme. Each process is in modular form, and each component can be activated/deactivated during a simulation. The two-way interactive nesting capabilities of the model allow the use of regional scale domains together with several high resolution nested domains. This feature is important for the purpose of the present work since it allows for simultaneous description of long range transport phenomena and aerosolcloud interactions at cloud resolving scales. The explicit twomoment cloud microphysics scheme of the model is used to describe the aerosol-cloud interactions. For clarity, the dust and sea salt cycles parameterization together with the deposition schemes are described in Appendix A. Radiative transfer and cloud droplet nucleation modules of the model are briefly described in the following sections.

\subsection{Radiation parameterization}

The basic options for shortwave/longwave radiative transfer in RAMS include the Chen and Cotton (1983) and the Harrington (1997) schemes. The former treats all hydrometeors as liquid-phase; the latter scheme includes three shortwave and five infrared bands interacting with ice and liquid condensates and with model gases. Radiation transfer 
Table 1. ICLAMS configuration options. New capabilities (compared to RAMS) are shown in bold.

\begin{tabular}{|c|c|}
\hline Basic Equations & Non hydrostatic time split compressible \\
\hline Dimensionality & $\begin{array}{l}2 \text { dimensional } \\
3 \text { dimensional }\end{array}$ \\
\hline Vertical Coordinate & $\begin{array}{l}\text { Standard Cartesian coordinate } \\
\text { Terrain following height coordinate }\end{array}$ \\
\hline Horizontal Coordinate & $\begin{array}{l}\text { Rotated polar-stereographic transformation } \\
\text { Lambert conformal transformation }\end{array}$ \\
\hline Grid Structure & $\begin{array}{l}\text { Arakawa-C grid stagger } \\
\text { Unlimited number of nested grids } \\
\text { User specified space and time step nesting ratios } \\
\text { Ability to add and subtract nests }\end{array}$ \\
\hline Time differencing & Hybrid combination of leapfrog and forward in time \\
\hline Turbulence closure & $\begin{array}{l}\text { Smagorinsky (1963) deformation K closure scheme with stability modifications made by Lilly (1962) and Hill (1974) } \\
\text { Deardorff level } 2.5 \text { scheme - eddy viscosity as a function of TKE } \\
\text { Mellor-Yamada level } 2.5 \text { scheme - ensemble averaged TKE Mellor and Yamada (1982) } \\
\text { Isotropic TKE parameterizations for high resolution simulations }\end{array}$ \\
\hline Cloud microphysics & $\begin{array}{l}\text { Warm rain processes } \\
\text { Five ice condensate species } \\
\text { Two-moment bulk scheme Walko et al. (1995); Meyers et al. (1997). } \\
\text { Cloud droplet activation scheme (Nenes and Seinfeld, 2003; Fountoukis and Nenes, 2005) }\end{array}$ \\
\hline Convective Parameterization & $\begin{array}{l}\text { Modified Kuo - Tremback (1990) } \\
\text { Kain-Fritsch cumulus parameterization }\end{array}$ \\
\hline Radiation & $\begin{array}{l}\text { Chen and Cotton (1983) long/shortwave model - cloud processes considering all condensate as liquid } \\
\text { Harrington (1997) long/shortwave model - two stream scheme interacts with liquid and ice hydrometeor size spectra and with dust particles } \\
\text { Rapid Radiative Transfer Model (RRTM) Mlawer et al. (1997); Iacono et al. (2000) with aerosol radiative effects }\end{array}$ \\
\hline Aerosol parameterization & $\begin{array}{l}\text { Mineral Dust } \\
\text { Sea salt spray } \\
\text { Anthropogenic aerosols (primary emissions and chemical formation) } \\
\text { Dry deposition } \\
\text { Wet deposition }\end{array}$ \\
\hline Emissions & $\begin{array}{l}\text { Anthropogenic emissions }\left(\mathrm{JRC} \mathrm{O.1}^{\circ} \times \mathrm{O.1}^{\circ} \text { global emissions of } \mathrm{CO}_{2}, \mathrm{NH}_{3}, \mathrm{CH}_{4}, \mathrm{SO}_{2}, \mathrm{NO}_{\mathrm{x}}, \mathrm{CO}, \mathrm{N}_{2} \mathrm{O}, \mathrm{VOCs}, \mathrm{OC} \& \mathrm{BC}\right) \\
\text { Biogenic emissions Gunther et al. }(1995) \\
\text { Any other emission inventory or combinations of more than one. }\end{array}$ \\
\hline Chemistry parameterization & $\begin{array}{l}\text { Online calculation of photodissociation rates } \\
\text { Online gas, aqueous and aerosol phase chemistry }\end{array}$ \\
\hline Lower boundary & $\begin{array}{l}\text { Soil - vegetation - snow parameterization (LEAF-3) (Walko et al., 2000) } \\
\text { Urban canopy scheme - 3-D field of drag coefficients based on building characteristics }\end{array}$ \\
\hline Boundary conditions & $\begin{array}{l}\text { Klemp and Wilhelmson (1978) radiative condition } \\
\text { Large-scale nudging boundary conditions Davies (1983) } \\
\text { Cyclic or periodic boundaries }\end{array}$ \\
\hline Initialization & $\begin{array}{l}\text { Horizontally homogeneous from a single sounding } \\
\text { RAMS/ISAN package - hybrid isentropic terrain following analysis using gridded larger scale model data (ECMWF, NCEP) } \\
\text { combined with a variety of observed data types Tremback (1990) } \\
\text { LAPS 3-D data assimilation pre-processing system }\end{array}$ \\
\hline Data Assimilation & $\begin{array}{l}\text { 4-D nudging to data analysis } \\
\text { Observational data nudging scheme based on 'direct' nudging to the observations }\end{array}$ \\
\hline
\end{tabular}

calculations options in ICLAMS have been extended with the implementation of the Rapid Radiative Transfer Model (RRTM) for both SW and LW bands (Mlawer et al., 1997; Iacono et al., 2000). RRTM is a spectral-band radiative transfer scheme based on the correlated $-k$ method (Lacis and Oinas, 1991; Fu and Liou, 1992). Pre-calculated look-up tables are used to simulate the impact of clouds and the impact of various atmospheric gases and aerosols in the distribution of the radiation along the atmosphere. For both Harrington and RRTM radiation options, the aerosol optical depth of prog- nostic dust has been added to the calculation of the total optical depth to account for its direct radiative forcing and photochemical impacts.

\subsection{Cloud droplet nucleation parameterization}

RAMS has been widely used for cloud research during the last two decades (Krichak and Levin, 2000; Mavromatidis and Kallos, 2003; Saleeby and Cotton, 2004; van den Heever et al., 2006; van den Heever and Cotton, 2007; Mavromatidis 
et al., 2007; Zhang et al., 2007 among others). The model is able to explicitly resolve a complete set of atmospheric processes at resolutions ranging from tens of kilometers down to a few meters. The nesting capabilities of the model allow for sufficient representation of microphysical processes at cloud scales. The microphysics scheme of RAMS includes seven condensate species (cloud droplets, rain droplets, pristine ice, snow, aggregates, graupel and hail) and vapor. The twomoment microphysics parameterization scheme treats both the mixing ratio and number concentration of each hydrometeor (Meyers et al., 1997). Prediction of cloud droplet number concentration is originally based on air temperature, vertical wind component and on a constant amount of available $\mathrm{CCN}$. A lookup table has been constructed offline from a detailed bin-parcel model and the number of activated CCN is calculated from this table. The size and chemical properties of the $\mathrm{CCN}$ are not taken into consideration. This approach has been altered in the new version of the model by adding an explicit cloud droplet nucleation parameterization scheme (Nenes and Seinfeld, 2003; Fountoukis and Nenes, 2005). This scheme (referred to as FNS), provides a comprehensive microphysical link between aerosols and clouds. FNS computes droplet number based on the parcel framework, and solves for the maximum supersaturation, $s_{\max }$, that develops given a set of cloud-scale dynamics (temperature, pressure and vertical wind component) and aerosol properties (number concentration, size distribution and chemical composition). The droplet number is then equal to the number of CCN with critical supersaturation less or equal to $s_{\max }$ (Nenes and Seinfeld, 2003). The water vapour uptake coefficient, used in calculating the mass transfer coefficient of water vapour to growing droplets (Fountoukis and Nenes, 2005 ), is set to 0.06 based on in-situ cloud droplet closure experiments (Meskhidze et al., 2005; Fountoukis et al., 2007).

Soil dust, sea salt spray and secondary pollutants contribute to the $\mathrm{CCN}$ population. Dust particles are assumed to follow a lognormal size distribution at source regions. The properties of these distributions (number mean diameter and geometric dispersion) are expected to change throughout their atmospheric lifetime. These properties are explicitly calculated at every model step based on the predicted dust concentration (Schulz et al., 1998). CCN concentrations are expressed as a function of supersaturation using Köhler theory (Köhler, 1936; Nenes and Seinfeld, 2003). Freshlyemitted mineral dust particles have long been known to act as effective ice nuclei (Pruppacher and Klett, 1997; DeMott et al., 2003; Levin et al., 2005). Ice production is generally facilitated over regions with high mineral dust concentrations, such as over the Atlantic Ocean during African dust transportation episodes (Astitha et al., 2010). In ICLAMS, the insoluble fraction of dust contributes to the prognostic iceforming nuclei (IFN) following the formulation of Meyers et al. (1992).

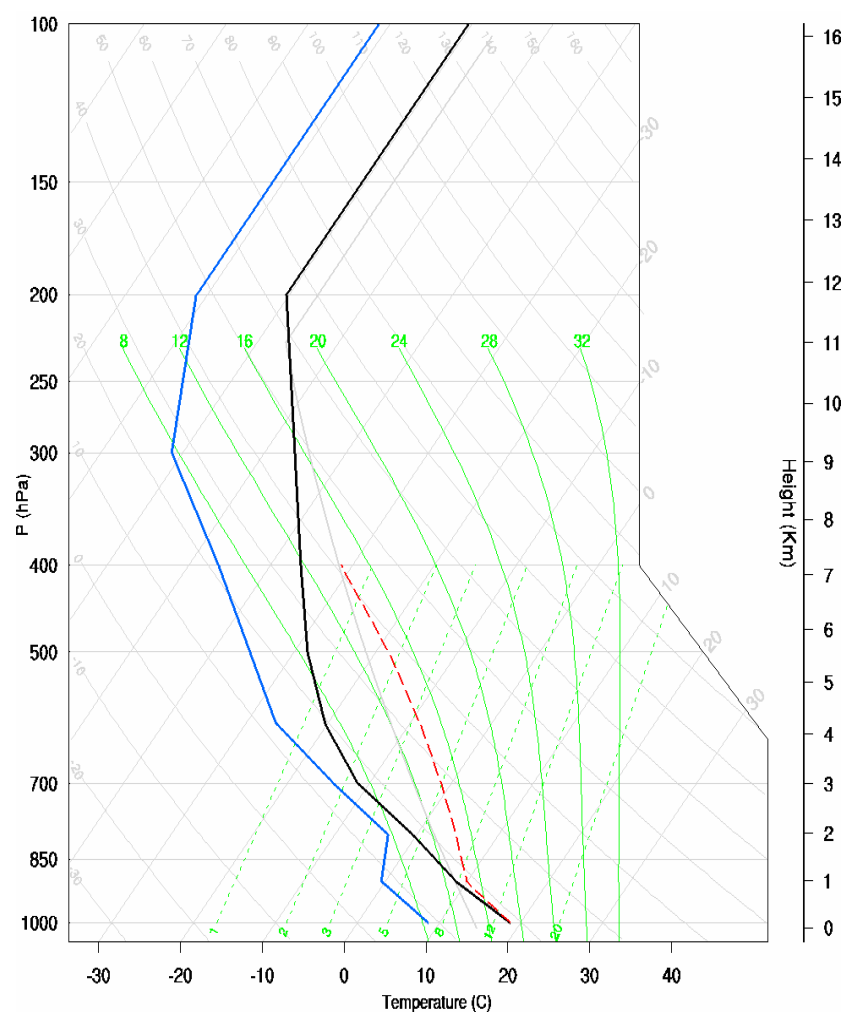

Fig. 1. Initial conditions for the thermodynamic profile of the atmosphere.

\section{Clouds and precipitation in an environment with natural particles}

\subsection{Idealized simulations}

In order to examine the sensitivity of the new cloud nucleation scheme to aerosol properties, we performed a set of "idealized" simulations for a convective cloud system over flat terrain. The model was configured on a two-dimensional domain with horizontal uniform resolution of $300 \mathrm{~m}$ and 35 vertical levels, starting from $50 \mathrm{~m}$ spacing near the ground and extending up to $18 \mathrm{~km}$ with a geometric stretching ratio of 1.2. The horizontal dimension of the domain was $24 \mathrm{~km}$. The model was initialized from a convectively unstable sounding (Fig. 1) that is considered as representative of winter convective clouds for the Eastern Mediterranean region (Yin et al., 2002; Levin et al., 2005). Initial wind conditions of $3 \mathrm{~m} \mathrm{~s}^{-1}$ wind speed and a westerly wind direction were applied homogeneously over the domain. The FNS parameterization was invoked in every time step and grid point and the number of activated droplets was calculated from grid-cell aerosol, $P, T$, and updraft velocity. All tests were performed with exactly the same configuration except for the aerosol properties. Each run started at 12:00 UTC and lasted for six hours. 
Table 2. Hourly accumulated precipitation over all the domain and maximum values for the number concentration and mixing ratio of cloud, rain and pristine-ice condensates, for two air mass type scenarios.

\begin{tabular}{|c|c|c|c|c|c|c|c|c|}
\hline $\begin{array}{l}\text { Time after } \\
\text { model start } \\
\text { (h) }\end{array}$ & $\begin{array}{l}\text { Aerosol } \\
\text { scenario }\end{array}$ & $\begin{array}{r}\text { Total accumulated } \\
\text { precipitation } \\
(\mathrm{mm})\end{array}$ & $\begin{array}{r}\text { Cloud No } \\
\text { concentration } \\
{\left[\mathrm{cm}^{-3}\right]}\end{array}$ & $\begin{array}{r}\text { Cloud } \\
\text { mixing ratio } \\
{\left[\mathrm{g} \mathrm{kg}^{-1}\right]}\end{array}$ & $\begin{array}{r}\text { Rain No } \\
\text { concentration } \\
{\left[\mathrm{L}^{-1}\right]}\end{array}$ & $\begin{array}{r}\text { Rain mixing } \\
\text { ratio } \\
{\left[\mathrm{g} \mathrm{kg}^{-1}\right]}\end{array}$ & $\begin{array}{r}\text { Pristine-ice } \\
\text { No concentration } \\
{\left[\mathrm{L}^{-1}\right]}\end{array}$ & $\begin{array}{r}\text { Pristine-ice } \\
\text { mixing ratio } \\
{\left[\mathrm{g} \mathrm{kg}^{-1}\right]}\end{array}$ \\
\hline \multirow[t]{2}{*}{2} & PRISTINE & 84 & 130 & 0.76 & 27.65 & 0.47 & 207 & 0.13 \\
\hline & HAZY & 26 & 2133 & 0.48 & 2.20 & 0.37 & 444 & 0.19 \\
\hline \multirow[t]{2}{*}{3} & PRISTINE & 74 & 99 & 0.08 & 3.19 & 0.22 & 89 & 0.05 \\
\hline & HAZY & 101 & 1363 & 0.39 & 2.47 & 0.33 & 115 & 0.05 \\
\hline \multirow[t]{2}{*}{4} & PRISTINE & 98 & 22 & 0.05 & 1.28 & 0.14 & 88 & 0.05 \\
\hline & HAZY & 67 & 592 & 0.13 & 2.98 & 0.09 & 97 & 0.06 \\
\hline \multirow[t]{2}{*}{5} & PRISTINE & 23 & 111 & 0.08 & 1.85 & 0.12 & 81 & 0.05 \\
\hline & HAZY & 20 & 377 & 0.44 & 2.24 & 0.09 & 94 & 0.05 \\
\hline \multirow[t]{2}{*}{6} & PRISTINE & 7 & 97 & 0.31 & 2.97 & 0.08 & 109 & 0.06 \\
\hline & HAZY & 3 & 231 & 0.12 & 2.04 & 0.03 & 74 & 0.04 \\
\hline
\end{tabular}

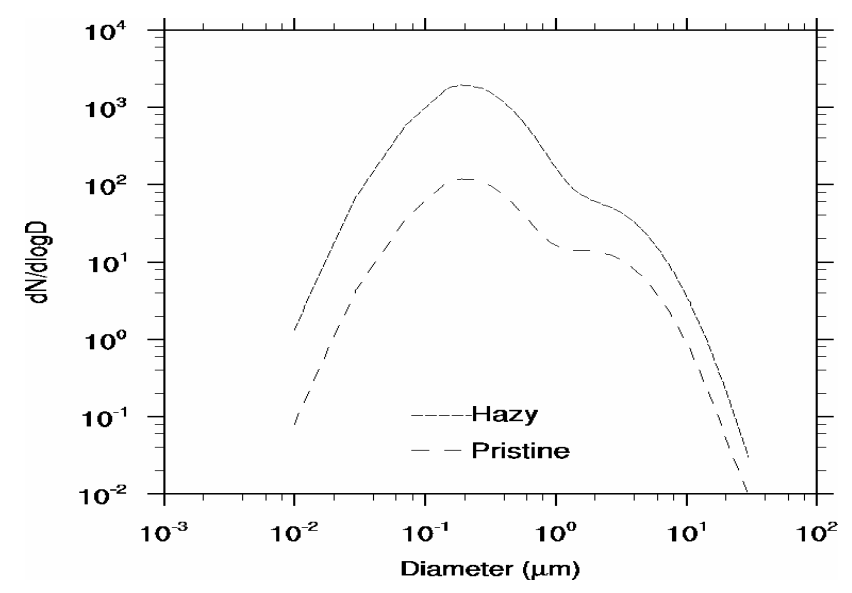

Fig. 2. Distribution of the available aerosol particles.

\subsubsection{Cloud processes for a pristine and a hazy environment}

Two scenarios were considered for the initial distribution of aerosol concentration, namely the "pristine" and the "hazy" scenario as illustrated in Fig. 2. The "pristine" scenario is representative of a remote area with a relatively clean atmosphere of total particle concentration $100 \mathrm{~cm}^{-3}$, while the "hazy" scenario assumes a total concentration of $1500 \mathrm{~cm}^{-3}$ similar to Teller and Levin (2006). Such high aerosol concentrations can be found near urban areas or industrial zones and are also typical during intense dust episodes. The size distribution of the particles was considered to follow a bimodal lognormal distribution that does not change shape between scenarios. The geometric standard deviation equals two for both modes, while the number median diameter was set at $0.2 \mu \mathrm{m}$ for the first mode and at $2 \mu \mathrm{m}$ for the second mode.
The chemical composition for the soluble fraction of the particles was assumed to be ammonium sulfate and the aerosol field was applied homogeneously throughout the model domain. Further development of the cloud system and the final amount of precipitation depend on the cloud microphysical structure and on the interplay with ambient dynamics. Both runs started developing a similar cloud structure after 80 min of simulation time and, as seen in Fig. 3, two distinctive convective areas were identified within a horizontal distance of about $15 \mathrm{~km}$. However, after the initial development, the cloud properties varied significantly between the "pristine" and "hazy" scenarios. These changes are reflected in the hourly accumulated precipitation over the entire domain and in the maximum values of mixing ratios and number concentrations for cloud droplets, rain droplets and pristine ice particles that are summarized in Table 2 for each model run.

In the "pristine" simulation, the cloud droplets number concentration remained low (maximum of $130 \mathrm{~cm}^{-3}$ ) throughout the simulation. Fewer $\mathrm{CCN}$ had to compete for the same amount of water. So, large cloud and rain droplets were allowed to develop and the collection efficiency was enhanced. This allowed for increased autoconversion rates of cloud to rain droplets and early initiation of warm rain process. Intense precipitation started $100 \mathrm{~min}$ into the simulation, with precipitation rates reaching as high as $15 \mathrm{~mm} \mathrm{~h}^{-1}$ (Fig. 4). The high rain mixing ratio peak value $\left(0.47 \mathrm{~g} \mathrm{~kg}^{-1}\right)$ and corresponding rain drop number concentration of $27.651^{-1}$ indicate the dominance of collisioncoalescence during the early stages of the cloud.

In contrast, during the "hazy" aerosol environment, initiation of precipitation was delayed. The number of cloud droplets for the "hazy" scenario was extremely high, especially during the first two hours of cloud development and reached $2133 \mathrm{~cm}^{-3}$ after $120 \mathrm{~min}$ of run. As a result, the conversion rates of cloud droplets to rain droplets were very low 

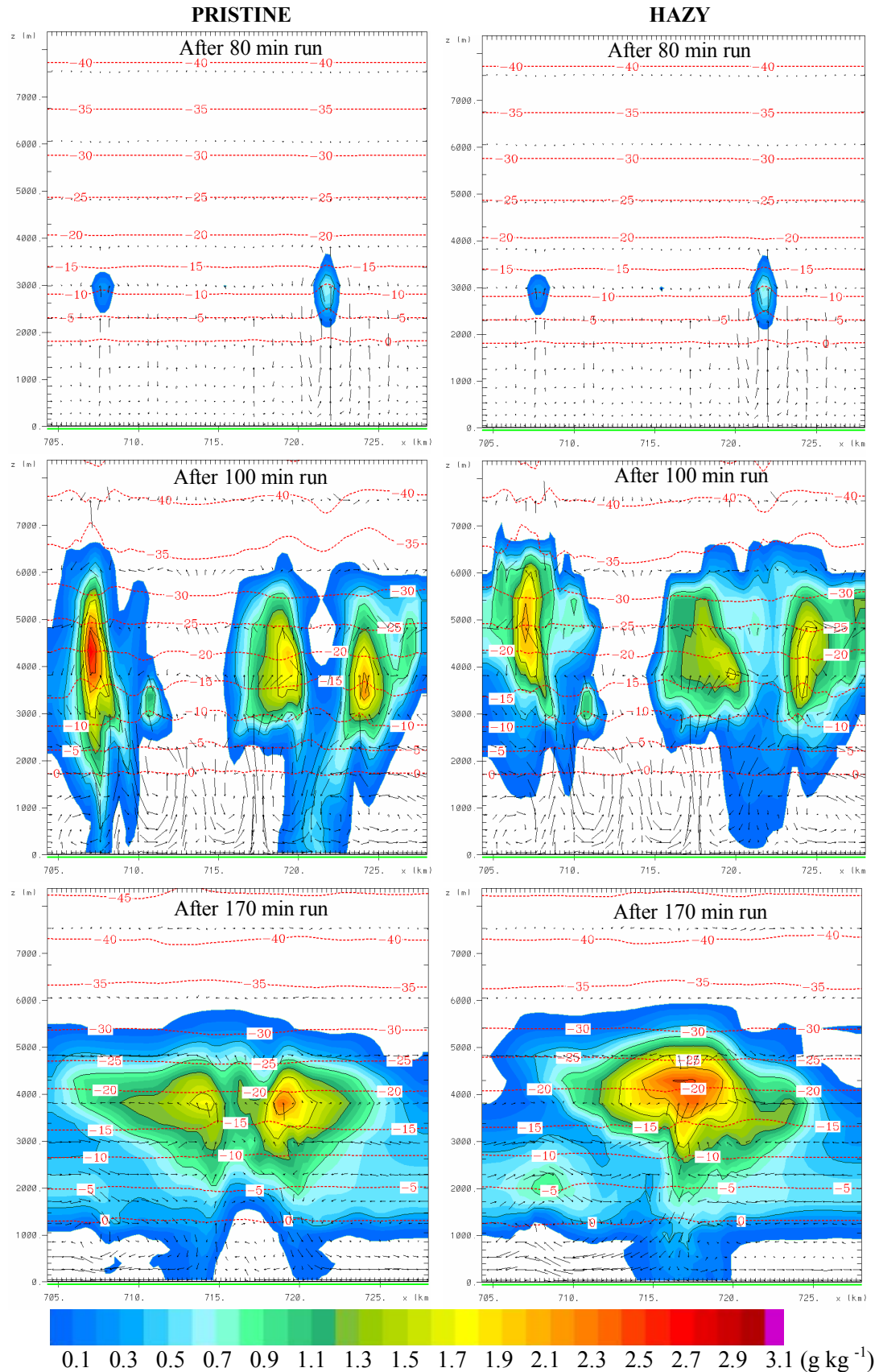

Fig. 3. Total condensates mixing ratio $\left(\mathrm{g} \mathrm{kg}^{-1}\right)$ for the "pristine" (left column) and the "hazy" (right column) scenarios.

and precipitation was inhibited. Maximum precipitation rate at this stage was only $4 \mathrm{~mm} \mathrm{~h}^{-1}$ which is about 4 times less than the "pristine" scenario. However, the ice particles were almost double that of the "pristine" cloud and rain droplets coming from the melting of ice condensates produced a significant amount of rain between 150 and 210 min model time as seen also in Fig. 4a. The accumulated precipitation over the entire domain was $286 \mathrm{~mm}$ for the "pristine" and $215 \mathrm{~mm}$ for the "hazy" case. Most of this difference can be attributed to the inhibition of precipitation during the early stages of cloud development as illustrated in Fig. 4a. Cloud structure was also very different between the two simulations. This is clearly shown in Fig. 3. Two separate cloud systems were still distinct after $170 \mathrm{~min}$ of simulation for the "pristine" case while during the "hazy" case the two clouds had merged to one cell and an anvil was formed at the upper cloud layers. Both systems continued precipitating with lower rates until the end of the simulation. 


\subsubsection{Effects of GCCN on clouds and precipitation}

The impact of giant cloud condensation nuclei (GCCN) is also important for cloud processes and precipitation (Teller and Levin, 2006; van den Heever et al., 2006). When aerosol sizes are comparable to cloud droplet size - which is often the case for dust and sea-salt, kinetic limitations are imposed on cloud nucleation processes (Barahona et al., 2010). Neglecting such effects may result in significant overestimation of activated cloud droplet number and in reduction of precipitation rates. Nucleation of GCCN is parameterized in the model using the approach of Barahona et al. (2010). In order to examine the impact of GCCN on precipitation, we added a third coarser mode to the aerosol distribution. The third mode was assumed to have a median diameter of $10 \mu \mathrm{m}$ a standard deviation of 2 and a total concentration of $5 \mathrm{~cm}^{-3}$. Adding GCCN to a hazy environment limited the number of cloud droplets that nucleated and as seen in Fig. 4b the rainfall during the early stages of cloud development was increased. On the other hand, GCCN did not change significantly the warm stage precipitation for the pristine environment (Fig. 4c). Precipitation rate was mainly affected by the number of activated cloud droplets. During the "pristine" case the clouds contained limited number of droplets which allowed them to grow fast to rain droplets. Adding a few GCCN for this case did not significantly change the cloud droplet spectrum in the model and so rainfall was not affected.

\subsubsection{Effects of topography on the distribution of precipitation}

The simplistic approach to the interactions between airborne particles and clouds that is described in the previous sections is not always representative of real atmospheric conditions. For example, by adding topographic effects in a 3-D model configuration that is equivalent to the 2-D "pristine" and "hazy" model simulations resulted in substantially different spatial distribution of precipitation as shown in Fig. 5. During these simulations, all model parameters remained unchanged except the surface features (topography in this case). The same initial conditions as in previous runs were used (Fig. 1) and a westerly flow with initial wind speed of $3 \mathrm{~ms}^{-1}$ was considered for all runs. The impact of topography on precipitation was investigated for three cases, namely "flat terrain", "idealized hill" and "complex hilly area". The first case (flat terrain) considers no topographic features and uniform landscape (soil and vegetation classes). In this case, atmospheric stability and cloud microphysics are the governing factors for the evolution of the cloud system. As seen in Fig. 5 a, b, most of the precipitation was distributed over the western side of the domain for both "pristine" and "hazy" clouds but with different maxima ("pristine" case gave more precipitation). For the second run ("the idealized hill") the landscape remains the same as in the previous case but a
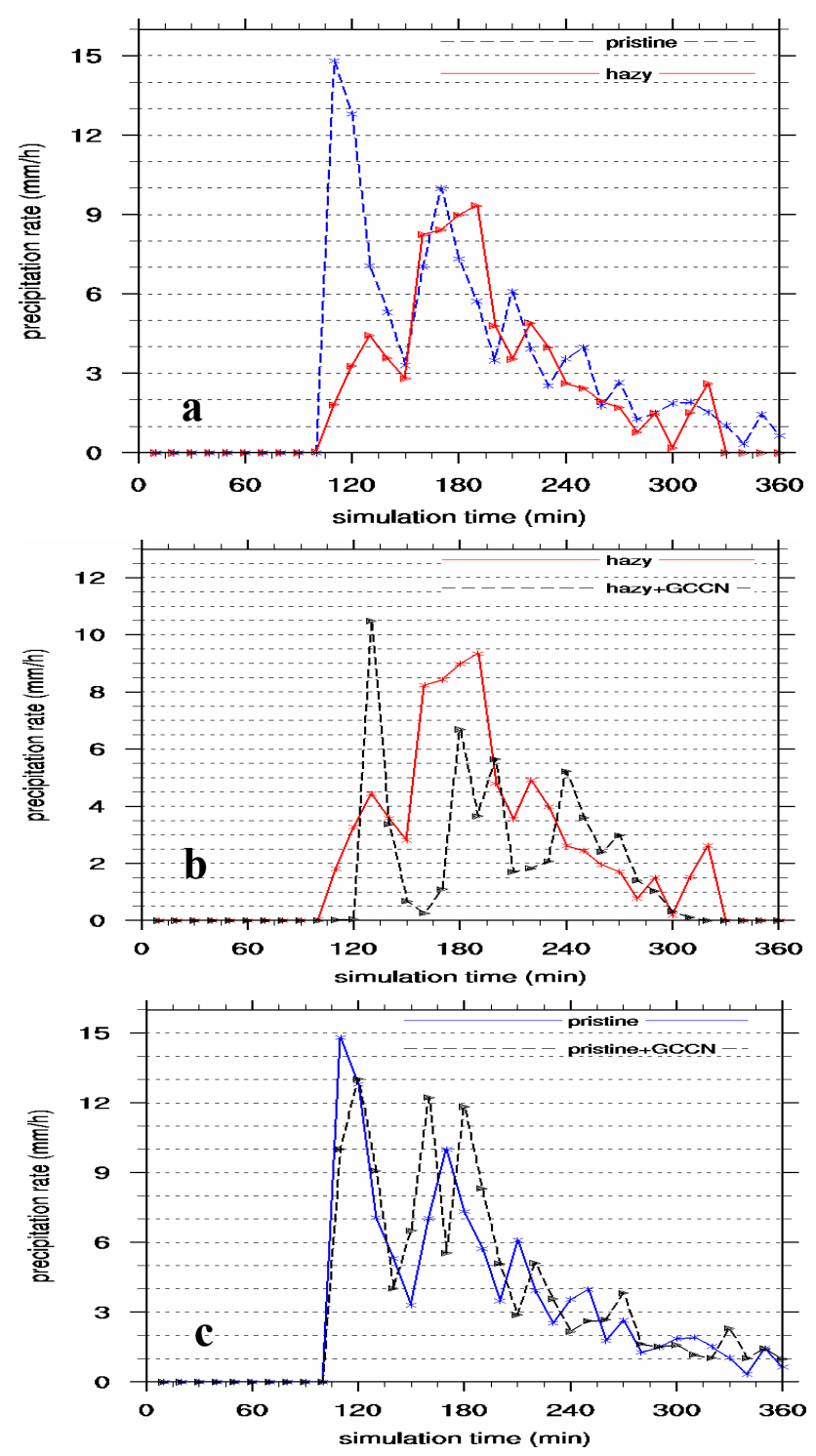

Fig. 4. Maximum precipitation rate $\left(\mathrm{mm} \mathrm{h}^{-1}\right)$ for: (a) the "pristine" and "hazy" aerosol scenarios. (b) the "hazy" and "hazy + GCCN" aerosol scenarios. (c) the "pristine" and "pristine + GCCN" aerosol scenarios.

$290 \mathrm{~m}$ high ridge with a $\mathrm{N}-\mathrm{S}$ uniform orientation is added at the center of the domain. The combination of microphysics and cloud dynamics due to mechanical elevation over the hill resulted in a substantially different precipitation pattern that is shown in Fig. 5 c, d. The distribution of precipitation for this case is clearly related to the location of the hill with more rain falling over the downwind area at the eastern part of the domain. Finally, the third case includes also the same landscape but the topography is representative of a complex hilly area with heights up to $700 \mathrm{~m}$. As illustrated in Fig. 5 e, $\mathrm{f}$, these topographic features resulted in a completely different distribution of precipitation. Such results indicate that 

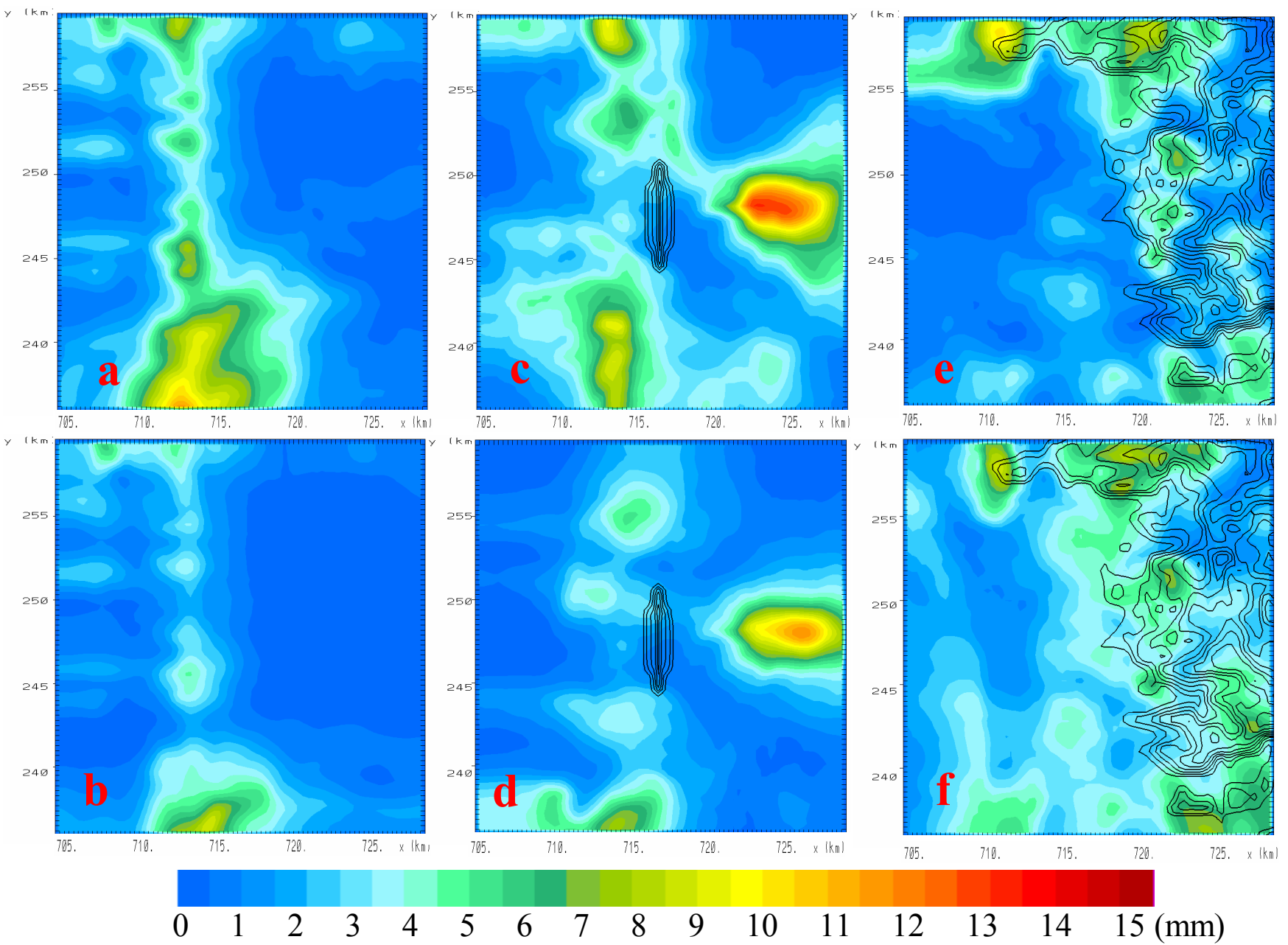

Fig. 5. Four hour accumulated precipitation (colour palette in $\mathrm{mm}$ ) and $50 \mathrm{~m}$ topographic line contours. 1st row (a, c, e): "pristine" aerosol. 2nd row (b, d, f): "hazy" aerosol. 1st column: No topography (flat terrain). 2nd column: artificial obstacle vertical to the general flow. 3rd column: complex topography. The domain total precipitation for each case is: (a) $12.28 \mathrm{~m}$, (b) $7.21 \mathrm{~m}$, (c) $16.77 \mathrm{~m}$ (d) $11.01 \mathrm{~m}$, (e) 12.97 , (f) 17.86

the synergetic effects between the microphysical and macrophysical parameters that contribute in cloud and precipitation processes should be taken into account in relevant modeling studies on a combined way. Otherwise, the results may be misleading when compared to real atmospheric conditions. For example, the "pristine" cases produced more accumulated precipitation than the "hazy" ones for the "flat terrain" and "idealized hill" cases. On the other hand, the accumulated precipitation over the "complex terrain" was increased during the "hazy" run. The distribution of precipitation was found to be much more sensitive to terrain variability than to any of the variations in aerosol properties.

\subsection{Case study}

We focus on a case study that combines a low pressure system and a dust storm over the eastern Mediterranean. On 28 January 2003, the centre of the low moved from Crete through Cyprus accompanied by a cold front. Also, prevailing south-westerly winds over North-eastern Africa transported dust particles towards the coast of Israel and Lebanon. As illustrated in Fig. 6, deep convective clouds were developed along the frontal line. These clouds moved north-eastward and on 29 January 2003, heavy rain and hail amounts were reported over the East Mediterranean coastline and a few kilometres inland. Flood events and agricultural disasters were also recorded. A detailed analysis and airborne measurements of this episode were obtained during the Mediterranean Israeli Dust Experiment (MEIDEX) as described in Levin et al. (2005). Several runs have been 


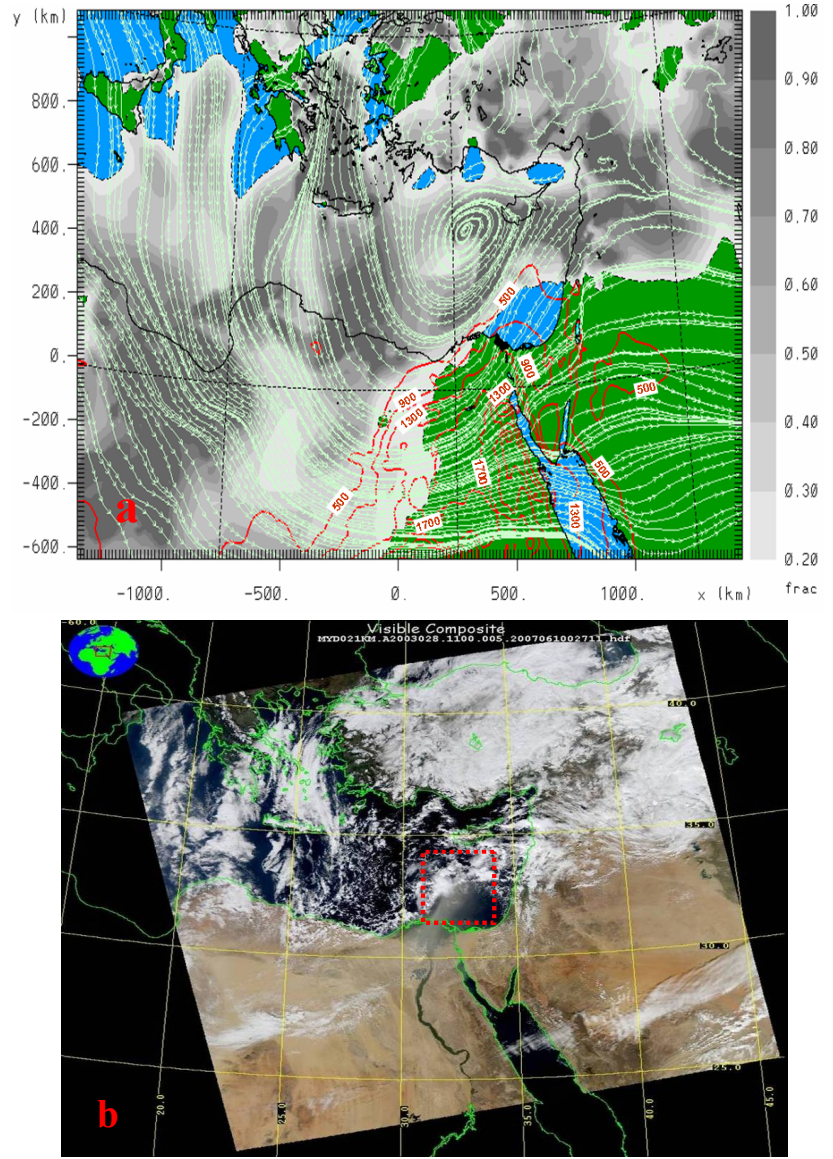

Fig. 6. (a) Cloud cover percentage (greyscale), streamlines at first model layer (green contours), dust - load (red contours in $\mathrm{mg} \mathrm{m}^{-2}$ ) and (b) MODIS-Aqua visible channel, on 28 January 2003 11:00 UTC. Dust transportation is obvious over the Southeastern part of Mediterranean. The red dashed rectangular indicates the location of convective clouds due to frontal uplift.

performed for this case. Special attention was given to the amount of available airborne particles that could act as CCN and GCCN for each particular case, examining both the effects on the precipitation reaching the ground and also the effects on the microphysical structure inside the clouds. Modelling results are compared to ground and aircraft observations and some of the findings are discussed here.

\subsubsection{Model configuration}

The model was configured with three nested grids $(15 \mathrm{~km}$, $3 \mathrm{~km}$ and $750 \mathrm{~m}$ ) as seen in Fig. 7 and with 32 vertical levels starting from $50 \mathrm{~m}$ above ground and stretching up to $18 \mathrm{~km}$ with a geometric ratio of 1.2 . For the initial and boundary conditions, a high resolution reanalysis dataset was used. This dataset has been prepared with the Local Analysis and Prediction System (LAPS) (Albers, 1995; Albers et al., 1996). LAPS uses an effective analysis scheme to harmonize data of different temporal and spatial resolutions on a regular grid. The prepared dataset includes 24 years of reanalysis (1986-2009) with a grid resolution of $15 \times 15 \mathrm{~km}$ and temporal intervals of $3 \mathrm{~h}$. It is based on the ECMWF operational analysis dataset (with resolution of $0.5 \times 0.5^{\circ}$ as initial guess fields and the utilization of all available surface and upper air measurements. The sea surface temperature (SST) used is the NCEP $0.5^{\circ} \times 0.5^{\circ}$ analysis. The model was run for a two days period (26-27 January 2003) prior to the actual event to allow the establishment of an aerosol background. The test case run started at 28 January 00:00 UTC and lasted for $48 \mathrm{~h}$. During these simulations only dust and sea salt particles were included as aerosols in the model. The main dust sources were located in North East Libya and North West Egypt as illustrated in Fig. 7. Sea salt particles were assumed to be completely soluble and contributed to the $\mathrm{CCN}$ population. The chemical properties of dust particles are in general associated with the chemical transformations that occur during their atmospheric lifetime. Aged dust clouds include particles that are coated with sea-salt or sulfates (Levin et al., 1996; Bougiatioti et al., 2009). Dust and sea salt particles are treated separately for transportation and deposition processes and there is no explicit interaction between them in the model. However, salt-coated dust particles are also efficient $\mathrm{CCN}$. This behavior is implicitly parameterized in the model by assuming fixed percentages of soluble dust particles for each particular case. These values are used to describe the partitioning between hygroscopic and non-hygroscopic dust particles and represent average conditions for the area.

\subsubsection{Aerosol properties and comparison with aircraft measurements}

Consistent with Levin et al. (2005), the aerosol particles within the lowest two kilometers of the atmosphere were a mixture of dust and sea-salt. The south-to-north and westto-east vertical cross sections of Fig. 8 indicate that the dust particles did not elevate higher than two kilometers in the atmosphere and coexisted with sea salt spray particles along their transportation path. The increased aerosol concentration near the cloud base affected the formation of clouds in this area.

The number concentration of modelled dust and sea salt particles was tested against in-situ aircraft observations that were performed (between 07:30 and 09:30 UTC) at various heights inside the dust-storm area. Detailed information about the aircraft instrumentation, the sampling and averaging techniques and the variability in particle measurements is provided in Levin et al. (2005). According to their description, the aircraft was flying with a constant speed of $70 \mathrm{~m} \mathrm{~s}^{-1}$ and covered a distance of about $125 \mathrm{~km}$ inside the stormy area. Two optical particle counters were used for the measurements of the aerosol size distributions and concentrations. The first was used for aerosols between $0.1-3 \mu \mathrm{m}$ in diameter and the second for aerosols between $2-16 \mu \mathrm{m}$ 


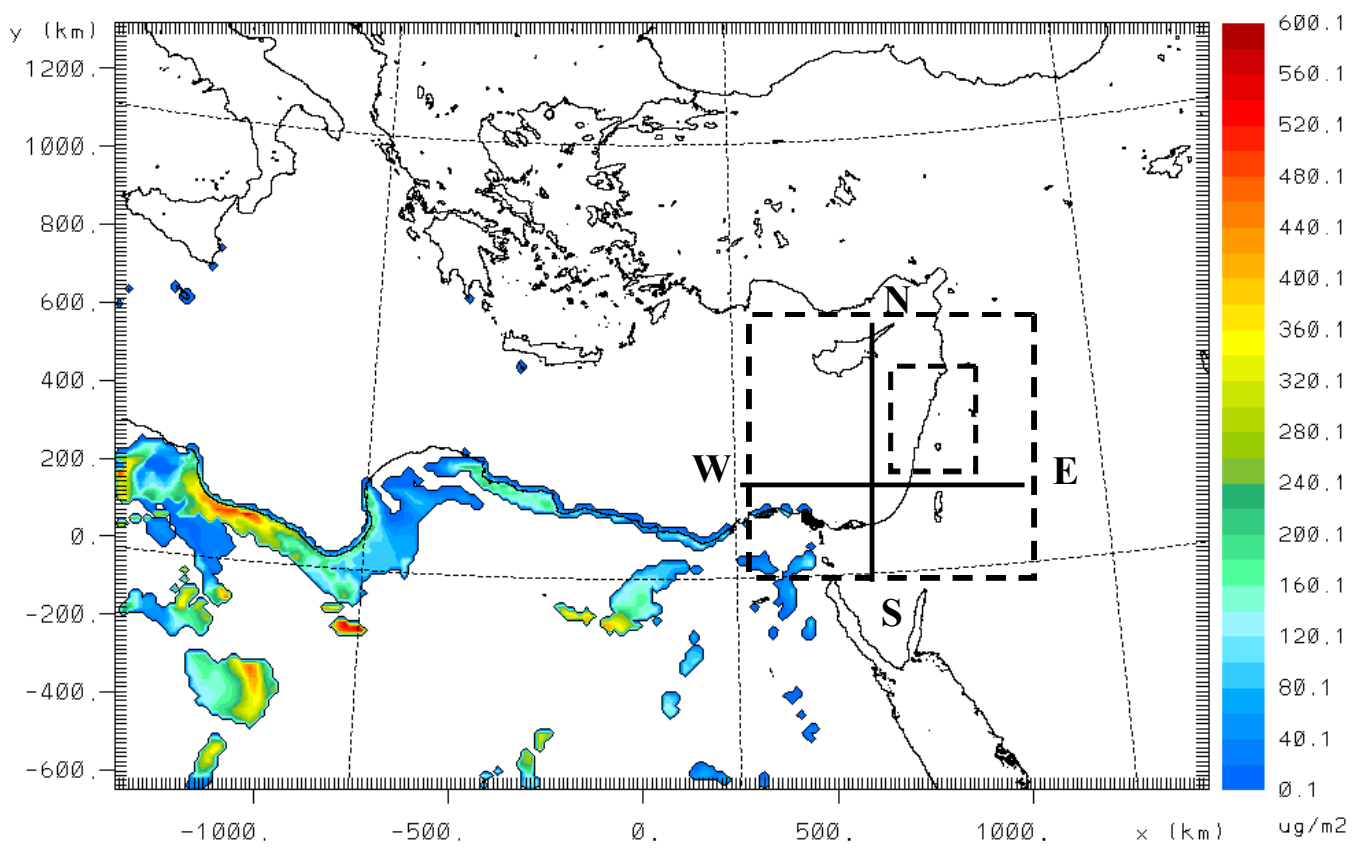

Fig. 7. Dust flux in $\mu \mathrm{g} \mathrm{m}^{-2}$ on 27 January 2003 09:00 UTC. Dashed rectangles indicate the location of the nested domains. Solid lines indicate the locations of the cross sections of Fig. 8.

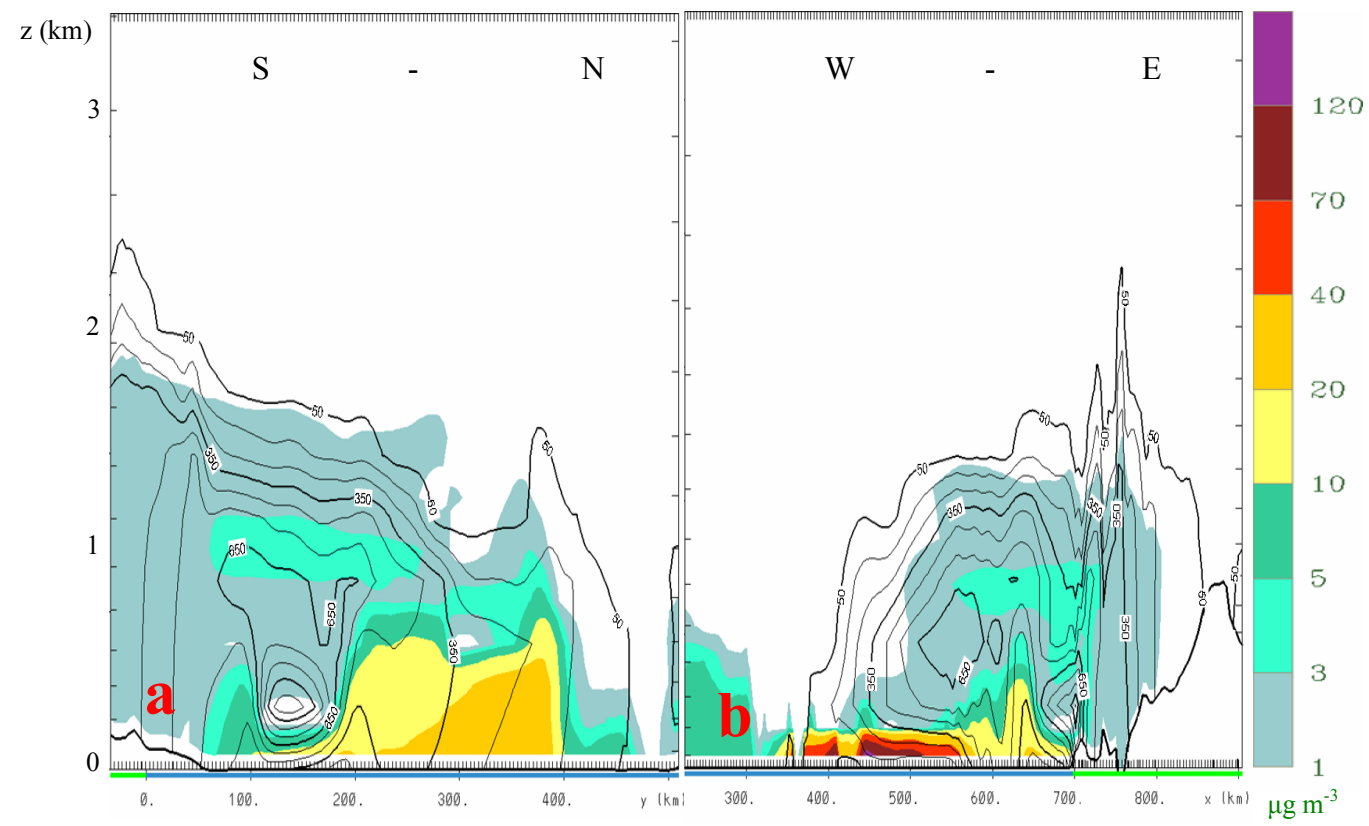

Fig. 8. (a) Vertical cross sections of dust concentration (black line contours in $\mu \mathrm{g} \mathrm{m}^{-3}$ ) and (b) sea salt concentration (color palette in $\mu \mathrm{g} \mathrm{m}^{-3}$ ).

in diameter flayer are in satisfactory. Measurements were performed in an irregular manner along the aircraft path and each sampling period lasted for five minutes. For the current work, the average concentration of natural particles for each measurement point is compared towards the corresponding model results. In order to co-locate the aircraft measure- ments with the appropriate model grid point we considered the mean geographic location of the aircraft for each sampling period. The simulated dust and salt concentrations for the corresponding location in the model is then calculated as the weighted average from the eight nearest model grid points. The concentrations of modelled particles inside the 


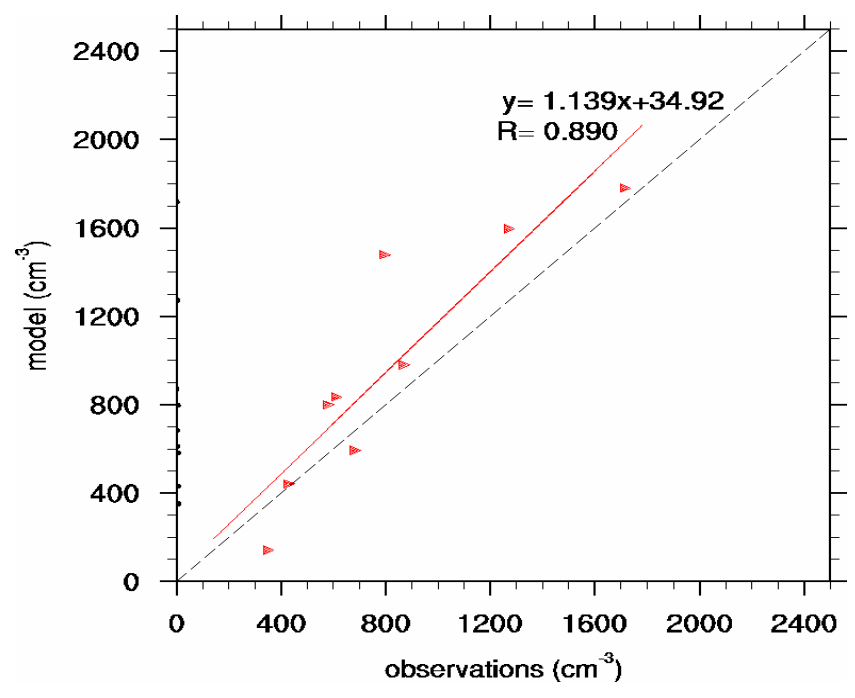

Fig. 9. Comparison of aircraft measurements of natural particles with modeled dust and salt concentrations inside the dust layer (below $2 \mathrm{~km}$ ). The red line indicates the linear regression line while the dotted line indicates the $y=x$ line.

dust layer are in satisfactory agreement with airborne measurements as illustrated in Fig. 9, with a correlation coefficient $R=0.89$. These results indicate that the model is able to quantitatively reproduce the horizontal and vertical structure of the dust storm. The ability of the model to capture these features is important for the next steps of the experiment, since the estimated particles contribute to the cloud droplet nucleation mechanism. As seen in Fig. 10, the dust storm is approaching the coast of East Mediterranean from south-west during the morning of 28 January 2008. The clouds that were formed in this area were affected by the dust storm and also by the increased sea salt production due to the relatively strong winds and wind shear. The coexistence of salt and dust particles at heights below cloud base provided significant amounts of highly hygroscopic mixed particles. These clouds contained increased numbers of cloud droplets and moved north-northeast towards the Israel and Lebanon coast. Most of the precipitation from these clouds fell after they reached land and the peak rain rates were reported on the morning of 29 January 2003 around Haifa and North Israel.

Three different scenarios related to the properties of the aerosol particles during the model runs are discussed here. All model parameters were held constant except the percentage of dust particles containing soluble material, thus becoming effective CCN. In experiment 1 (EXP1), $5 \%$ of dust particles were hygroscopic while for experiment 2 (EXP2), this percentage was increased to $20 \%$. DeMott et al. (2003a), found that during intense dust episodes, the concentration of ice nuclei (IN) was increased by 20-100 times compared to non-dust environment. Following this approach, EXP3 incorporated 5\% hygroscopic dust while the concentration of

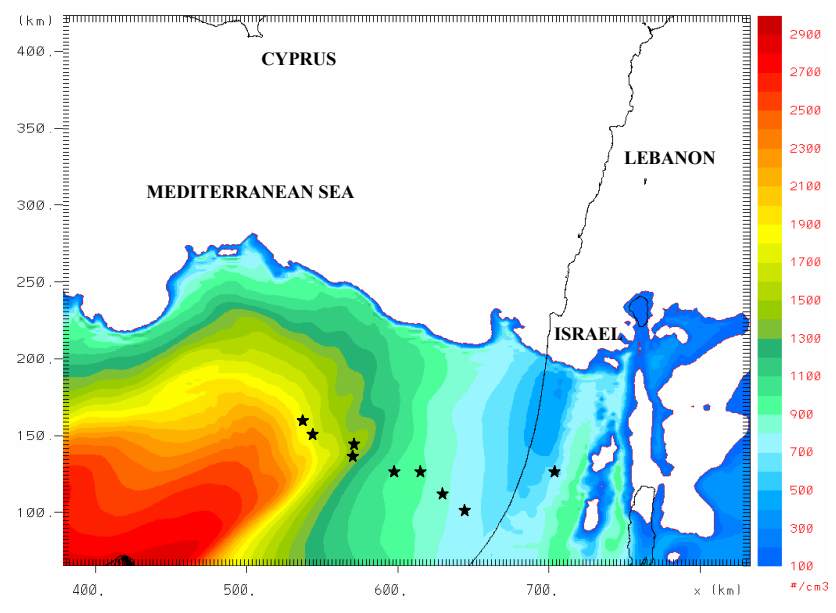

Fig. 10. Modeled dust number concentration $\left(\mathrm{cm}^{-3}\right)$ at $538 \mathrm{~m}$ height on 28 January 2003, 09:20 UTC. Dots indicate the locations of the aircraft measurements.

IN in the model was multiplied by a factor of ten in the presence of mineral dust. The hygroscopic dust particles were assumed to contain 33\% sodium chloride. The aerosol spectrum was fitted in a 3-modal lognormal distribution. The first mode corresponds to particles of mineral dust origin while the other two correspond to sea-salt accumulation and coarse modes, respectively. The median diameter and standard deviation for the accumulated salt mode is $0.36 \mu \mathrm{m}$ and 1.8 , respectively. For the coarse salt mode the median diameter is $2.85 \mu \mathrm{m}$ and the standard deviation is 1.9 . However, dust particles may range from small submicron diameters (away from the sources and at high atmospheric levels) up to GCCN sizes (near sources and at low atmospheric levels). In order to represent this kind of inhomogeneous spatial distribution, the median diameter and standard deviation for the dust mode are estimated from the relative prognostic concentrations of the eight dust bins according to Schulz et al. (1998).

Increasing the percentage of hygroscopic dust particles from $5 \%$ to $20 \%$ increased also the concentration of small liquid droplets inside the cloud. This resulted in lower autoconversion rates of cloud to rain droplets and significant amount of water was lifted to above freezing level. The EXP2 clouds reached higher tops, included more ice water content and the initiation of rainfall was in general delayed by almost $1 \mathrm{~h}$. In Fig. 11, the cloud that was formed in the more pristine environment (EXP1) reached the maximum top at 09:00 UTC. The EXP2 cloud extended much higher (about $3 \mathrm{~km}$ higher than EXP1), contained more ice, and eventually produced more rain (one hour later than EXP1; 10:00 UTC instead of 09:00 UTC). The EXP3 cloud also exhibited significant vertical development, with a structure and precipitation amounts similar to that of EXP2. Mineral dust particles affect the microphysical structure of the clouds by acting both as CCN, GCCN and IN and also by interacting with cloud dynamics. As illustrated in Fig. 12a for the EXP2 


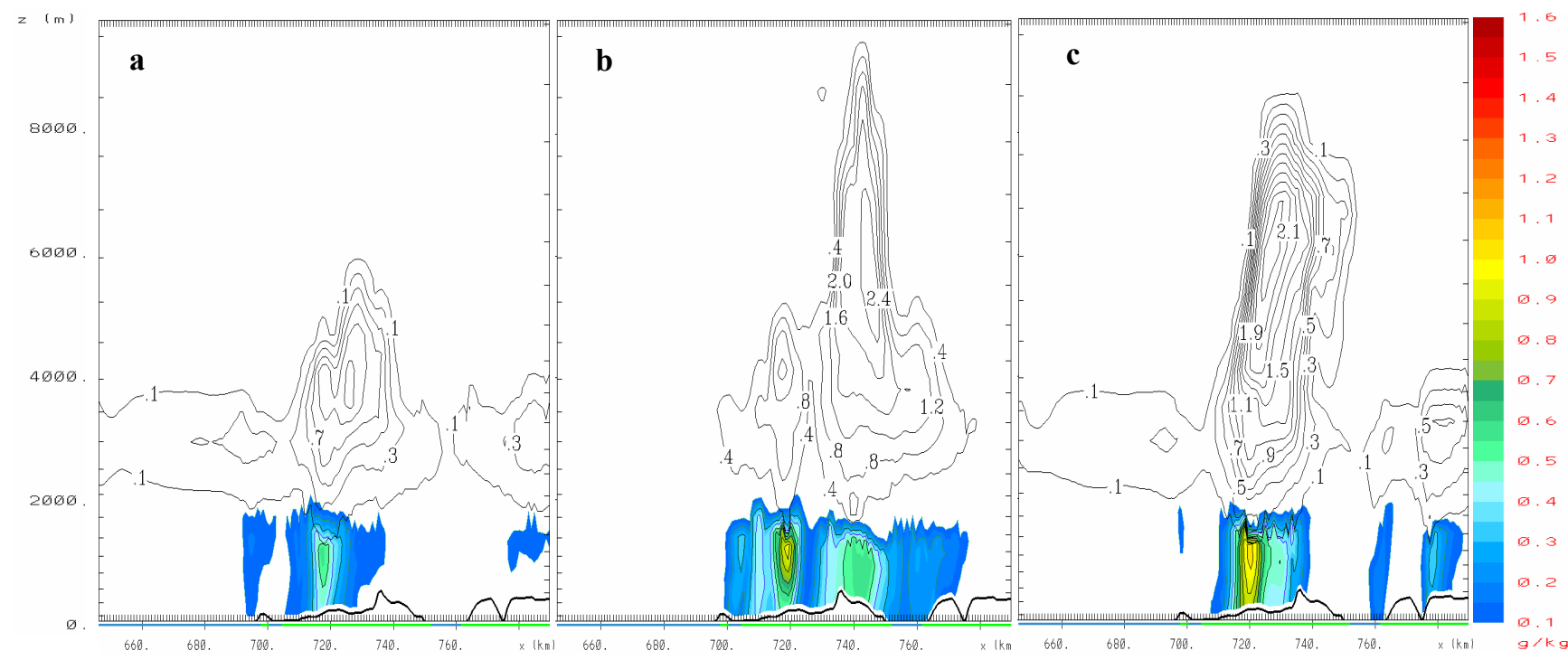

Fig. 11. West to East cross-section of rain mixing ratio (color palette in $\mathrm{g} \mathrm{kg}^{-1}$ ) and ice mixing ratio (red line contours in $\mathrm{g} \mathrm{kg}^{-1}$ ) at the time of highest cloud top over Haifa. (a) 09:00 UTC 29 January 2003 assuming 5\% hygroscopic dust (EXP1). (b) 10:00 UTC 29 January 2003 assuming 20\% hygroscopic dust (EXP2). (c) 09:00 UTC 29 January 2003 assuming 5\% hygroscopic dust and IN $\times 10$ (EXP3).

Table 3. Model characteristics for nine aerosol scenarios.

\begin{tabular}{lll}
\hline Aerosol Cases & $\begin{array}{l}\text { Aerosol-cloud } \\
\text { interaction }\end{array}$ & $\begin{array}{l}\text { Aerosol-radiation } \\
\text { interaction }\end{array}$ \\
\hline Case1 (control run) & NO & NO \\
Case2 (only radiation interaction) & NO & YES \\
Case3 (constant aerosol - "pristine") & YES & NO \\
Case4 (constant aerosol - "hazy") & YES & NO \\
Case5 (prognostic aerosol - 1\% hygroscopic dust) & YES & YES \\
Case6 (prognostic aerosol - 5\% hygroscopic dust) & YES & YES \\
Case7 (prognostic aerosol - 10\% hygroscopic dust) & YES & YES \\
Case8 (prognostic aerosol - 30\% hygroscopic dust) & YES & YES \\
Case9 (prognostic aerosol - 5\% hygroscopic dust + IN $\times 10)$ & YES & YES \\
\hline
\end{tabular}

case, there was significant convective activity over Haifa at 08:20 UTC on 29 January and the convective available potential energy (CAPE) was $1027 \mathrm{~J}$. When CAPE is large enough, significant amounts of liquid condensates may thrust into the upper levels of a cloud (Fig. 12b) and eventually freeze at higher altitudes. The released latent heat invigorates convection at higher levels, resulting in increase of the equivalent potential temperature (see Fig. $12 \mathrm{c}$ with an arrow pointing to the area of increased equivalent potential temperature). After $10 \mathrm{~min}$, strong updrafts reached up to $8 \mathrm{~km}$ height and transferred condensates to the upper cloud layers as illustrated in Fig. 12d. These condensates interact with the available IN in this region of the cloud, forming ice particles through heterogeneous nucleation. Thus, increasing the percentage of hygroscopic mineral dust or increasing the IN by an order of magnitude resulted in enhancement of ice particles formation and the release of latent heat at higher levels. These interactions between aerosols and cloud dynamics produce clouds with stronger updrafts that reach higher tops and finally produce heavier rainfall.

\subsubsection{Effects of natural particles on precipitation}

In order to examine the sensitivity of accumulated precipitation to aerosol properties, we performed a total of nine scenarios with the same model configuration but changing the chemical composition of airborne particles. The physio-chemical characteristics used on each run are shown in Table 3. The first run was performed with the original RAMS model and we call it "control run". For Case2, only particles-radiation interaction was enabled. For cases three and four, the FNS cloud nucleation parameterization was 

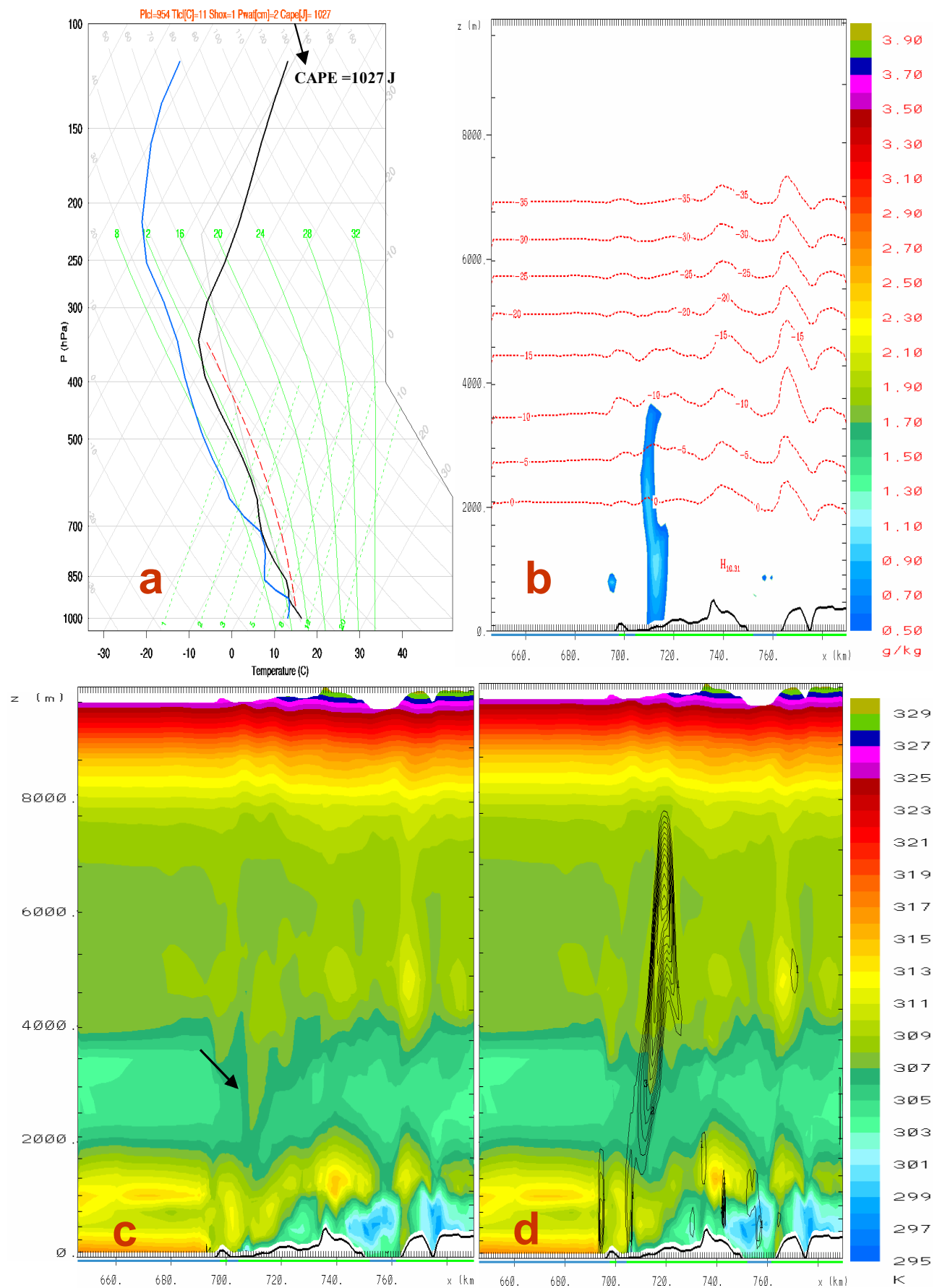

Fig. 12. (a) Modelled thermodynamic profile of the atmosphere over Haifa at 08:20 UTC, 29 January 2003 and W-E cross sections over Haifa for: (b) Liquid water mixing ratio (colour palette in $\mathrm{g} \mathrm{kg}^{-1}$ ) and ambient temperature (red contours in $\mathrm{C}^{\circ}$ ) at 08:20 UTC. (c) Equivalent potential temperature (colour palette in K) at 08:20 UTC. The arrow points at the area of increased $\theta_{\mathrm{e}}$. (d) Equivalent potential temperature (colour palette in $\mathrm{K}$ ) and updrafts (black contours in $\mathrm{m} \mathrm{s}^{-1}$ ) at 08:30 UTC. The plots refer to EXP2.

enabled using the prescribed "pristine" and "hazy" air mass types as in Sect. 3.1. For the next four runs, particle concentration was a prognostic variable and the cloud nucleation scheme was used in an explicit way. The percentage of hy- groscopic dust was set to be one (1\%), five (5\%), ten (10\%) and thirty per cent $(30 \%)$ respectively. For Case 9, we considered five (5\%) hygroscopic dust and also the IN concentration was increased by a factor of ten similar to Teller and 


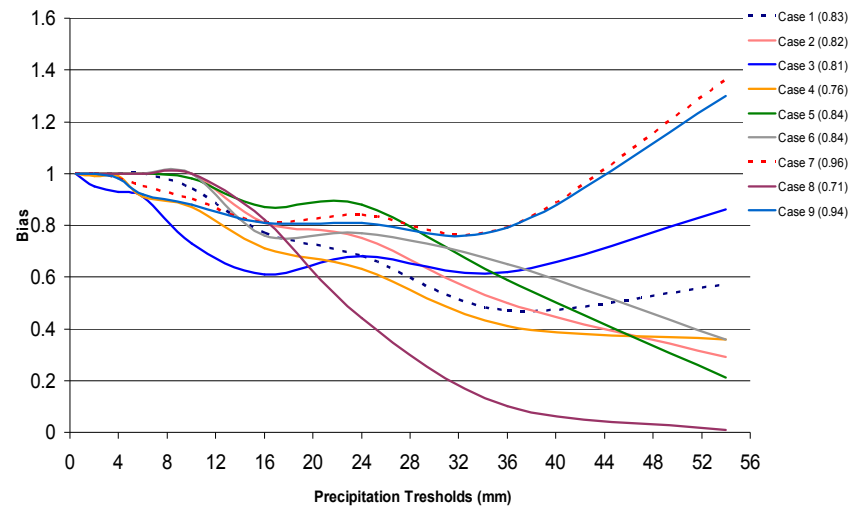

Fig. 13. Bias of the $24 \mathrm{~h}$ accumulated precipitation for 86 stations and for nine scenarios of aerosol composition. The average bias for each scenario is specified in parenthesis after the legend labels. The number of available stations for each threshold is also denoted in parenthesis after the precipitation heights: $0.5(86), 2(86), 4(86)$, 6 (86), 10 (84), 16 (81), 24 (57), 36 (34), 54 (14).

Levin et al. (2006). The modelled 24-hour accumulated precipitation on 29 January 2003 for all nine cases was tested against ground measurements from 86 measuring stations over North Israel.

The model bias score (see Appendix B) was calculated for nine thresholds of accumulated precipitation, namely $0.5 \mathrm{~mm}, 2 \mathrm{~mm}, 4 \mathrm{~mm}, 6 \mathrm{~mm}, 10 \mathrm{~mm}, 16 \mathrm{~mm}, 24 \mathrm{~mm}, 36 \mathrm{~mm}$ and $54 \mathrm{~mm}$. The results for each case and each precipitation threshold are shown in Fig. 13. Biases equal to one mean that the particular precipitation threshold was simulated as often as observed. Bias below unity indicates model underprediction and bias over one indicates over-prediction. The limited time period of the study and the relevant small number of measuring stations (especially at high thresholds) does not allow extracting robust statistical results. However, as seen in Fig. 13, the accumulated precipitation was found to be very sensitive to variations of the percentage of dust particles that can be activated as CCN and IN. These results indicate the need for a proper treatment of the links and feedbacks between cloud and aerosol processes. Model results with prognostic aerosol treatment were in general closer to the observations than those considering constant prescribed aerosol properties and the model bias for these cases was improved especially at medium and high precipitation heights. For example, at the $16 \mathrm{~mm}$ threshold, the bias ranged from 0.61 (Case 3) to 0.87 (Case 5). Similarly, for the $24 \mathrm{~mm}$ threshold the bias score ranged from 0.63 (Case 4) to 0.88 (Case 5) and for the $36 \mathrm{~mm}$ the bias was 0.1 for Case 8, 0.47 for the control run (Case 1) and 0.79 for Cases 7 and 9. The average bias for all thresholds was calculated for each one of the nine cases (see Appendix B for definition) and is also shown in Fig. 13. The variability in model bias was up to $80 \%$ for some thresholds which is indicative of the role of aerosol in atmospheric processes. During the eighth case, the accumulated precipitation field was clearly underestimated due to the increased concentration of hygroscopic particles for this case. Increasing the number of $\mathrm{CCN}$ delayed the initiation of precipitation and resulted in the enhancement of ice concentrations. These ice crystals did not grow much because of the lack of water drops at higher levels (in agreement with the results of Teller and Levin, 2006). Most of these clouds evaporated before they managed to precipitate and the accumulated precipitation was underestimated. These findings imply that a more detailed representation of the atmospheric composition and of the aerosol-cloud-radiation feedbacks can provide some insight into the processes involved in the formation of clouds and precipitation and also improve the model performance.

\section{Concluding remarks}

Several sensitivity tests were performed with an integrated atmospheric model that includes online parameterization of aerosol processes, aerosol-radiation interaction, explicit cloud droplet activation scheme and a complete microphysics package. Two- dimensional tests for an idealized case of cloud development indicated a significant response of cloud processes and precipitation to the variations of aerosol number concentration and also to the size distribution of the particles. "Hazy" aerosol conditions delayed precipitation while the clouds that were formed in a "pristine" environment precipitated faster and produced more rain, in agreement with earlier publications. However, in order to simulate the aerosol effects in an approach that is closer to realistic atmospheric conditions, it is also necessary to take into account the synergetic effects between the various microphysical and macrophysical processes. For example, the distribution of accumulated precipitation was found to be much more sensitive to topographic variations than to aerosol number concentration and/or composition.

Model simulations for a specific event of dust transport and convective activity over Eastern Mediterranean, illustrated that this kind of regional modeling approach can be very useful in reproducing many of the important features of aerosol and cloud processes. These findings can be summarized as follows:

1. The meteorological conditions during this particular event and the aerosol field properties were reproduced in the model in satisfactory agreement with observations. This is also indicated by the correlation factor of 0.89 between modelled aerosol concentrations and airborne measurements.

2. An increase of $15 \%$ in the concentration of soluble dust particles produced clouds that extended about three kilometres higher and the initiation of precipitation was delayed by almost one hour. 
3. Variations between $1-30 \%$ in the amount of dust particles that were assumed to contain soluble material resulted in significant changes in cloud properties. The associated variations in the precipitation bias score were up to $80 \%$ for some thresholds.

4. In general, online treatment of dust and salt particles as prognostic CCN, GCCN and IN improved the bias score for the $24 \mathrm{~h}$ accumulated precipitation in comparison to the runs considering a uniform atmospheric composition all over the domain.

These results illustrate the highly non-linear response of precipitation to aerosol properties and indicate that a large portion of uncertainty remains unresolved. This study focuses mostly on investigating the mechanisms that are associated with the aerosol cloud interactions for a specific event. Therefore it is not possible to extract generic results. Nevertheless, this work represents one of the first limited area modelling studies for aerosol-cloud-radiation effects at the area of Eastern Mediterranean and could be used as a basis for future improvements and longer term studies. More intense combined modeling and observational surveys on the interactions between airborne particles and cloud processes at regional and local scale are necessary in order to improve our knowledge on the interactions between atmospheric chemistry and meteorology.

\section{Appendix A Mineral Dust}

The dust-cycle simulation adopts the approach of the SKIRON/Dust model (Spyrou et al., 2010) and is based on the "saltation and bombardment" mechanism (Marticorena and Bergametti, 1995; Lu and Shao, 1999; Alfaro and Gomez, 2001; Grini et al., 2002). Based on this approach, the vertical dust flux is distributed into three lognormal source modes with different shapes and mass fractions (D'Almeida, 1987; Zender et al., 2003). The transport mode is represented inside the model with eight discrete size bins as in Pérez et al. (2006) and Spyrou et al. (2010) with effective radii of $0.15,0.25,0.45,0.78,1.3,2.2,3.8$, and $7.1 \mu \mathrm{m}$ respectively. Each dust bin is treated as a scalar variable for advection and diffusion purposes. Partitioning of the dust spectrum and separate treatment of each size mode is important for the description of size dependent processes such as dry and wet deposition, $\mathrm{CCN}$ activation and radiative transfer.

\section{A1 Sea salt spray}

The most prominent mechanism for the generation of sea salt aerosols is the bursting of entrained air bubbles during whitecap formation due to surface wind. The method follows the open sea white-cap formation as described in Monahan et al. (1986) which gives a continuous particle-size distribution at a specific relative humidity (RH), usually $80 \%$.

$$
\begin{aligned}
& \frac{d F_{\mathrm{N}-\text { Open }}}{d r_{80}}=1.373 \cdot u_{10}^{3.41} \cdot r_{80}^{-A} \cdot\left(1+0.057 r_{80}^{3.45}\right) \\
& \cdot 10^{1.607 e^{-B^{2}}} \\
& A=4.7 \cdot\left(1+\Theta r_{80}\right)^{-0.017 r_{80}^{-1.44}}, \Theta=30 \\
& B=\left(0.433-\log r_{80}\right) / 0.433
\end{aligned}
$$

where $u_{10}$ is the wind speed at $10 \mathrm{~m}$ height, and $r_{80}$ is the particle radius at $80 \% \mathrm{RH}$ as described in Zhang et al. (2005). This semi-empirical formulation is based on laboratory measurements for particles with radius $0.8-8 \mu \mathrm{m}$. The size range of the sea salt source function has been extended to below $0.1 \mu \mathrm{m}$ in radius based on the parameterization proposed by Gong (2003). Additionally, in order to take into account the hygroscopic nature of sea salt, the size distribution of the particles is calculated as a function of local RH following Zhang et al. (2005). This method accounts for the hygroscopic uptake of water from sea salt particles for $\mathrm{RH}$ values between $45 \%$ and $99 \%$. Coastline sea salt flux is also parameterized in the model following the work of Leeuw et al. (2000) and Gong et al. (2002).

Sea salt particle spectrum is represented with a bimodal lognormal distribution assuming a mean diameter of $0.36 \mu \mathrm{m}$ for the first (accumulated) mode and a mean diameter of $2.85 \mu \mathrm{m}$ for the second (coarse) mode. Geometric dispersion is 1.80 and 1.90 for the two modes respectively.

\section{A2 Dry deposition}

Dry deposition for dust and salt particles is treated as a first order removal process, equal to the concentration multiplied by a mass transfer coefficient, $V_{\mathrm{d}}$ (termed "deposition velocity"; Seinfeld and Pandis, 1998; Slinn and Slinn, 1980). $V_{\mathrm{d}}$ accounts for the effects of reactivity, hygroscopic water uptake, size distribution of particles, meteorological conditions and surface characteristics. Wesely (1989) proposed a resistance model to account for all the elements described above; dry deposition fluxes are controlled by gravitational settling, turbulent mixing, and Brownian diffusion across two virtual layers. In the layer adjacent to the surface, Brownian diffusion (for small particles) and gravitational settling (for large particles) are the main deposition processes. In the second layer, called the "constant flux layer", turbulent mixing and gravitational settling dominate deposition. $V_{\mathrm{d}}$ of a particle with a given diameter is then parameterized using a set of mass transfer resistances associated with the combined effects of these processes in both layers (Wesely, 1989; Seinfeld and Pandis, 1998):

$r_{\mathrm{a}}=\frac{1}{k u_{*}}\left[\ln \left(\frac{1}{z_{0}}\right)-\phi_{h}\right]$ 
$r_{\mathrm{b}}=\frac{1}{u_{*}\left(S_{c}^{-2 / 3}+10^{-3 / S_{t}}\right)}$

$V_{\mathrm{d}}=V_{\mathrm{sed}}+\frac{1}{r_{\mathrm{a}}+r_{\mathrm{b}}+r_{\mathrm{a}} r_{\mathrm{b}} V_{\mathrm{sed}}}$

where $r_{\mathrm{a}}$ is the aerodynamic resistance, $r_{\mathrm{b}}$ is the boundary resistance, $k$ is the von Karman constant, $z_{o}$ is the surface roughness length, $\phi_{h}$ a stability correction term, $S_{c}$ is the Schmidt number, $S_{t}$ is the Stokes number and $V_{\text {sed }}$ is the gravitational settling velocity.

\section{A3 Wet deposition}

Proper treatment of the wet removal process is essential for a realistic aerosol simulation, since it is the predominant removal process for atmospheric particles away from their sources. The amount of particles removed at each model time step from in-cloud and below-cloud scavenging is expressed as:

$$
\frac{\partial C}{\partial t}=-\Lambda C
$$

where $\Lambda$ is the "scavenging coefficient" of the aerosols. For in-cloud removal, $\Lambda$ is calculated from the droplet-aerosol collection efficiency $(E)$, the precipitation rate $(P)$ and the radius of the scavenging droplet $\left(r_{\mathrm{d}}\right)$ following the formulation of Seinfeld and Pandis (1998):

$$
\Lambda=\frac{3}{4} \frac{E P}{r_{\mathrm{d}}}
$$

The collection efficiency $(E)$ for a particle of radius $\left(r_{\mathrm{p}}\right)$ is calculated from the contribution of Brownian diffusion, turbulent diffusion, interception, inertial impaction and electric forces (Slinn, 1984; Seinfeld and Pandis, 1998):

$$
\begin{aligned}
E\left(r_{\mathrm{p}}\right) & =\frac{4}{\operatorname{Re} S_{c}}\left(1+0.4 \operatorname{Re}^{1 / 2} S_{c}^{1 / 3}+0.16 \operatorname{Re}^{1 / 2} S_{c}^{1 / 2}\right) \\
& +4 \phi\left[\frac{\mu}{\mu_{\mathrm{w}}}+\phi\left(1+\operatorname{Re} e^{1 / 2}\right)\right]+\left[\frac{S_{t}-S^{*}}{S_{t}-S^{*}+2 / 3}\right]^{3 / 2}
\end{aligned}
$$

where $R e$ is the droplet Reynolds number, $S_{c}$ is the particle Schmidt number, $r_{\mathrm{d}}$ is the droplet radius, $\phi=\frac{r_{\mathrm{p}}}{r_{\mathrm{d}}}, \mu, \mu_{\mathrm{w}}$ are the kinematic viscosities of the air and liquid water, respectively, $S_{t}$ is the particle Stokes number and

$$
S^{*}=\frac{1.2+\ln (1+R e) / 12}{1+\ln (1+R e)}
$$

\section{Appendix B}

For each model scenario (Cases 1-9) and for each precipitation threshold a contingency table is constructed as follows (Wilks, 2006):

\section{Observed}

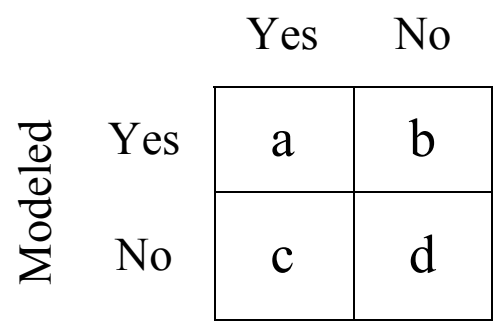

The $a$ model-observation pairs mean that both model and observation are over the specific threshold and are usually called hits. Similarly, $b$ pairs mean that the model is over the threshold but observation is below it and are called false alarms; $c$ pairs mean that the observation is over the threshold but the model is below it and are called misses and $d$ pairs mean that both model and observation are below the threshold for a station and are called correct rejections.

The total number of hits $(a)$, false alarms $(b)$ and misses (c) for each threshold are then used to calculate the MODEL $\operatorname{BIAS}(B)$ :

$B=\frac{a+b}{a+c}$

Unbiased forecasts exhibit bias $=1$, while bias greater than one indicates overprediction and bias less than one indicates underprediction.

The AVERAGE BIAS $(\bar{B})$ for all precipitation thresholds is calculated as:

$\bar{B}=\frac{1}{N} \sum_{i=1}^{i=N} B(i)$,

Where $B(i)$ is the bias for each specific threshold and $N$ is is the total number of precipitation thresholds.

Acknowledgements. This work has been supported by the European Union 6th Framework Program CIRCE IP, contract\# 036961 and EUROCONTROL Research Studentship Agreement no CO6/22048ST.

Edited by: M. Kanakidou

\section{References}

Albers, S. C.: The LAPS wind analysis, Weather Forecast., 10, 342352, 1995.

Albers, S., McGinley, J. A., Birkenheuer, D., and Smart, J. R: The Local Analysis and Prediction System (LAPS): Analysis of clouds, precipitation, and temperature, Weather Forecast., 11, 273-287, 1996.

Albrecht, B. A.: Aerosols, cloud microphysics, and fractional cloudiness, Science 245, 1227-1230, 1989.

Alfaro, S. C. and Gomes, L.: Modeling mineral aerosol production by wind erosion: emission intensities and aerosol size distributions in source areas, J. Geophys. Res., 106(D16), 18075-18084, 2001. 
Andreae, M. O., Charlson, R. J., Bruynseels, F., Storms, H., van Grieken, R., and Maenhaut, W.: Internal mixtures of sea salt, silicates and excess sulfate in marine aerosols, Science, 232, 1620$1623,1986$.

Andreae, M. O. and Rosenfeld, D.: Aerosol-cloud-precipitation interactions, Part 1, The nature and sources of cloud-active aerosols, Earth Sci. Rev., 89, 13-41, 2008.

Astitha, M. and Kallos, G.: Gas-phase and aerosol chemistry interactions in South Europe and the Mediterranean Region, Env. Fl. Mech., 9(1), 3-22, doi:10.1007/s10652-008-91107, 2008.

Astitha, M., Kallos, G., Spyrou, C., O’Hirok, W., Lelieveld, J., and Denier van der Gon, H. A. C.: Chemically aged and mixed aerosols over the Central Atlantic Ocean - potential impacts, Atmos. Chem. Phys. 10, 5797-5822, 1020 doi:10.5194/acp-10$5797,2010$.

Barahona, D., West, R. E. L., Stier, P., Romakkaniemi, S., Kokkola, H., and Nenes, A.: Comprehensively accounting for the effect of giant $\mathrm{CCN}$ in cloud activation parameterizations, Atmos. Chem. Phys., 10, 2467-2473, doi:10.5194/acp-10-2467-2010, 2010.

Bougiatioti, A., Fountoukis, C., Kalivitis, N., Pandis, S. N., Nenes, A., and Mihalopoulos, N.: Cloud condensation nuclei measurements in the marine boundary layer of the Eastern Mediterranean: CCN closure and droplet growth kinetics, Atmos. Chem. Phys., 9, 7053-7066, doi:10.5194/acp-9-7053-2009, 2009.

Charlson, R. J., Langner, J., and Rodhe, H.: Sulphate aerosol and climate, Nature, 348, 94 pp., 1990.

Charlson, R. J., Schwartz, S. E., Hales, J. M., Cess, R. D., Coakley, J. A., Hansen, J. E., and D. J., Hofmann: Climate forcing by anthropogenic aerosols, Science, 255, 423-430, 1992.

Charlson, R. J., Seinfeld, J. H., Nenes, A., Kulmala, M., Laaksonen, A., and Facchini, M. C.: Reshaping the Theory of Cloud Formation, Science, 292, 2025-2026, 2001.

Chen, C. and Cotton, W. R.: A one-dimensional simulation of the stratocumulus-capped mixed layer, Bound.-Lay Meteor., 25, 289-321, 1983.

Chung, S. H. and Seinfeld, J. H.: Global distribution and climate forcing of carbonaceous aerosols, J. Geophys. Res., 107(D19), 4407, doi:10.1029/2001JD001397, 2002.

Cotton, W. R., Pielke Sr., R. A., Walko, R. L., Liston, G. E., Tremback, C. J., Jiang, H., McAnelly, R. L., Harrington, J. Y., Nicholls, M. E., Carrio, G. G., and Mc Fadden, J. P.: RAMS 2001: Current status and future directions, Meteorol. Atmos. Phys., 82, 5-29, 2003.

Cotton, W. R., Zhang, H., McFarquhar, G. M., and Saleeby, S. M.: Should we consider polluting hurricanes to reduce their intensity?, J. Wea. Mod., 39, 70-73, 2007.

D'Almeida, G. A.: On the variability of desert aerosol radiative characteristics, J. Geophys. Res., 92(D3), 3017-3026, 1987

Davies, H. C.: Limitations of some common lateral boundary schemes used in regional NWP models, Mon. Weater Rev., 111, 1002-1012, 1983.

DeMott, P. J., Sassen, K., Poellet, M. R., Baumgardner, D., Rogers, D. C., Brooks, S. D., Prenni, A. J. and Kreidenweis, S. M.: African dust aerosols as atmospheric ice nuclei, Geophys. Res. Lett., 30, 1732, doi:10.1029/2003GL017410, 2003.

Dockery, D. W. and Pope, C. A.: Acute respiratory effects of particulate air pollution, Annu. Rev. Publ. Health, 15, 107-132, 1994.

Fountoukis, C. and Nenes, A.: Continued Development of a Cloud Droplet Formation Parameterization for Global Climate Mod- els, J. Geophys. Res., 110, D11212, doi:10.1029/2004JD005591, 2005.

Fountoukis, C., Nenes, A., Meskhidze, N., Bahreini,, R., Conant, W. C., Jonsson, H., Murphy, S., Sorooshian, A., Varutbangkul, V., Brechtel, F., Flagan, R. C., and Seinfeld, J. H.: Aerosol cloud drop concentration closure for clouds sampled during the International Consortium for Atmospheric Research on Transport and Transformation 2004 campaign, J. Geophys. Res., 112, D10S30, doi:10.1029/2006JD007272, 2007.

$\mathrm{Fu}, \mathrm{Q}$. and Liou, K. N: On the correlated k-distribution method for radiative transfer nonhomogeneous atmosphere, J. Atmos. Sci., 49, 2139-2156, 1992.

Gong, S. L.: A parameterization of sea-salt aerosol source function for sub- and super-micron particles, Global Biogeochem. Cy., 17, 1097, doi:10.1029/2003GB002079, 2003.

Gong, S. L., Barrie, L. A., and Lazare, M.: Canadian Aerosol Module (CAM): a size-segregated simulation of atmospheric aerosol processes for climate and air quality models. 2. Global seasalt aerosol and its budgets, J. Geophys. Res., 107(D24), 4779, doi:10.1029/2001JD002004, 2002.

Grini, A., Zender, C. S., and Colarco, P. R.: Saltation sandblasting behavior during mineral dust aerosol production, Geophys. Res. Lett., 29, 1868, doi:10.1029/2002GL015248, 2002.

Harrington, J. Y.: The Effects of Radiative and Microphysical Processes on Simulated Warm and Transition Season Arctic Stratus., Ph.D. Thesis, Colorado State University, Ft. Collins, CO, 298 pp., 1997.

Herut, B., Collier, R., and Krom, M. D.: The role of dust in supplying nitrogen and phosphorus to the Southeast Mediterranean, Limnol. Oceanogr., 47, 870-878, 2002.

Hill, G. E.: Factors controlling the size and spacing of cumulus clouds as revealed by numerical experiments, J. Atmos. Sci., 31, 646-673, 1974.

Iacono, M. J., Mlawer, E. J., Clough, S. A., and Morcrette, J. J.: Impact of an improved longwave radiation model, RRTM, on the energy budget and thermodynamic properties of the NCAR Community Climate Model, CCM3, J. Geophys. Res., 105, 1487314890, 2000.

IPCC: Changes in atmospheric constituents and radiative forcing: Climate change 2007: the physical science basis, Cambridge University Press, New York, USA, and Cambridge, UK, 2007.

Jacobson, M. Z.: Global direct radiative forcing due to multicomponent anthropogenic and natural aerosols, J. Geophys. Res., 106, 1551-1568, 2001.

Junkermann, W., Hacker, J., Lyons, T., and Nair, U.: Land use change suppresses precipitation, Atmos. Chem. Phys., 9, 65316539, doi:10.5194/acp-9-6531-2009, 2009.

Kallos, G., Papadopoulos, A., Katsafados, P., and Nickovic, S.: Trans-Atlantic Saharan dust transport: Model simulation and results, J. Geophys. Res., 111, D09204, doi:10.1029/2005JD006207, 2006.

Kallos, G., Astitha, M., Katsafados, P., and Spyrou, C.: LongRange Transport of Anthropogenically and Naturally Produced particulate matter in the Mediterranean and North Atlantic: Current State of Knowledge, J. Appl. Meteorol. Clim., 46, 12301251, doi:10.1175/JAM2530.1, 2007.

Karyampudi, V. M.: A detailed synoptic-scale study of the structure, dynamics, and radiative effects of the Saharan air layer over the eastern tropical Atlantic during GARP Atlantic Tropical Ex- 
periment, M. S. thesis, Department of Meteorology, The Pennsylvania State University, 136 pp., 1979.

Karyampudi, V. M., Palm, S. P., Reagen, J. A., Fang, H., Grant, W. B., Hoff, R. M., Moulin, C., Pierce, H. F., Torres, O., Browell, E. V., and Melfi, S. H.: Validation of the Saharan dust plume conceptual model using lidar, Meteosat, and ECMWF data, B. Am. Meteor. Soc., 80, 1045-1075, 1999.

Krichak, S. O. and Levin, Z.: On the cloud microphysical processes during the 2 November 1994, hazardous storm in the southeastern Mediterranean as simulated with mesoscale model, Atmos. Res., 53, 63-89, 2000.

Klemp, J. B. and Wilhelmson, R. B.: The simulation of threedimensional convective storm dynamics, J. Atmos. Sci., 35, 10701096, 1978 .

Köhler, H.: The nucleus in and the growth of hygroscopic droplets, Trans. Faraday Soc., 32, 1151-161, 1936.

Lacis, A. A. and Oinas, V.: A description of the correlated $\mathrm{k}$ distributed method for modeling nongray gaseous absorption, thermal emission, and multiple scattering in vertically inhomogeneous atmospheres, J. Geophys. Res., 96, 9027-9063, doi:10.1029/90JD01945, 1991.

Lau, K. M., Kim, M. K., and Kim, K. M.: Aerosol induced anomalies in the Asian summer monsoon: The role of the Tibetan Plateau, Clim. Dynam., 26(7-8), 855-864, doi:10.1007/s003820 06-0114-z, 2006.

Lau, K. M. and Kim, K. M.: Observational relationships between aerosol and Asian monsoon rainfall, and circulation, Geophys. Res. Lett., 33, L21810, doi:10.1029/2006GL027546, 2006.

Lau, K. M., Kim, K. M., Sud, Y. C., and Walker, G. K.: A GCM study of the response of the atmospheric water cycle of West Africa and the Atlantic to Saharan dust radiative forcing, Ann. Geophys., 27, 4023-4037, doi:10.51941Angeo-27-4023-2009, 2009.

Leeuw, G., Neele, F. P., Hill, M., Smith, M. H., and Vignali, E.: Production of sea spray aerosol in the surf zone, J. Geophys. Res.Atmos., 105, 29397-29409, 2000.

Levin, Z. and Cotton, W. R.: Aerosol Pollution Impact on Precipitation-A Scientific Review, Springer, 386 pp., ISBN:9781-4020-8689-2, 2009.

Levin, Z., Ganor, E., and Gladstein, V.: The effects of desert particles coated with sulfate on rain formation in the eastern Mediterranean, J. Appl. Meteorol., 35, 1511-1523, 1996.

Levin, Z., Teller, A., Ganor, E., and Yin, Y.: On the interactions of mineral dust, sea-salt particles and clouds: A measurement and modeling study from the Mediterranean Israeli Dust Experiment campaign, J. Geophys. Res., 110, D20202, doi:10.1029/2005JD005810, 2005.

Lilly, D. K.: On the numerical simulation of buoyant convection, Tellus XIV, 148-172, 1962.

Lohmann, U. and Feichter, J.: Global indirect aerosol effects: a review, Atmos. Chem. Phys., 5, 715-737, doi:10.5194/acp-5-7152005, 2005.

Lu, H. and Shao, Y.: A new dust model for dust emission by saltation bombardment, J. Geophys. Res., 104, 16827-16841, 1999.

Lynn, B., Khain, A., Dudhia, J., Rosenfeld, D., Pokrovsky, A., and Seifert, A.: Spectral (bin) microphysics coupled with a mesoscale model (MM5). Part 2: Simulation of a CaPe rain event with squall line, Mon. Weather Rev., 133, 59-71, 2005b.

Mahowald, N., Jickells, T. D., Baker, A. R., Artaxo, P., Benitez-
Nelson, C. R., Bergametti, G., Bond, T. C., Chen, Y., Cohen, D. D., Herut, B., Kubilay, N., Losno, R., Maenhaut, C. L. W., McGee, K. A., Okin, G. S., Siefert, R. L., and Tsukuda, S.: Global distribution of atmospheric phosphorus sources, concentrations and deposition rates, and anthropogenic impacts, Global Biogeochem. Cy., 22, GB4026, doi:10.1029/2008GB003240, 2008.

Marticorena, B. and Bergametti, G.: Modeling the atmospheric dust cycle: 1 . Design of a soil derived dust emission scheme, J. Geophys. Res., 100(D8), 16415-16430, 1995.

Mavromatidis, E. and Kallos, G.: An investigation of cold cloud formation with a 3-D model with explicit microphysics, J. Geophys. Res., 108(D14), 4420, doi:2002JD0027111, 2003.

Mavromatidis, E., Lekas, T., and Kallos, G.: Analysis of a two-layer cloud system with RAMS model and comparison to airborne observations, Env. Fluid Mech., 7, 537-568, doi:10.1007/s10652007-9043-6, 2007.

Mellor, G. L. and Yamada, T.: Development of a turbulence closure model for geophysical fluid problems, Rev. Geophys. Space. Phys., 20, 851-875, 1982.

Meskhidze, N. and Nenes, A.: Phytoplankton and Cloudiness in the Southern Ocean, Science, 314, 1419-1423, 2006.

Meskhidze, N., Chameides, W. L., Nenes, A., and Chen, G.: Iron mobilization in mineral dust: Can anthropogenic SO2 emissions affect ocean productivity?, Geophys. Res. Lett., 30(21), 2085, doi:10.1029/2003GL018035, 2003.

Meskhidze, N., Chameides, W. L., and Nenes, A.: Dust and pollution: A recipe for enhanced ocean fertilization?, J. Geophys. Res., 110, D03301, doi:10.1029/2004JD005082, 2005.

Meyers, M. P., DeMott, P. J., and Cotton, W. R.: New primary ice nucleation parameterizations in an explicit cloud model, J. Appl. Meteor., 31, 708-721, 1992.

Meyers, M. P., Walko, R. L., Harrington, J. Y., and Cotton, W. R.: New RAMS cloud microphysics parameterization, Part II: The two-moment scheme, Atmos. Res., 45, 3-39, 1997.

Mitsakou, C., Kallos, G., Papantoniou, N., Spyrou, C., Solomos, S., Astitha, M., and Housiadas, C.: Saharan dust levels in Greece and received inhalation doses, Atmos. Chem. Phys., 8, 71817192, doi:10.5194/acp-8-7181-2008, 2008.

Mlawer, E. J., Taubman, S. J., Brown, P. D., Iacono, M. J., and Clough, S. A.: Radiative transfer for inhomogeneous atmospheres: RRTM, a validated correlated-k model for the longwave, J. Geophys. Res., 102(D14), 16663-16682, 1997.

Monahan, E. C., Spiel, D. E., and Davidson, K. L.: A model of marine aerosol generation via whitecaps and wave disruption, in: Oceanic Whitecaps, edited by: Monahan, E. C. and Mac Niocaill, G., D. Reidel, 167-174, 1986.

Myhre, G., Grini, A., Haywood, J. M., Stordal, F., Chatenet, B., Tanr, D., Sundet, J. K. and Isaksen, I. S. A.: Modelling the radiative impact of mineral dust aerosol during the Saharan Dust Experiment (SHADE) campaign, J. Geophys. Res., 108(D18), 8579, doi:10.1029/2002JD002566, 2003.

Nenes, A. and Seinfeld, J. H.: Parameterization of cloud droplet formation in global climate models, J. Geophys. Res., 108, 4415, doi:10.1029/2002JD002911, 2003

Nenes, A., Charlson, R. J., Facchini, M. C., Kulmala, M., Laaksonen, A., Seinfeld, J.H.: Can Chemical Effects on Cloud Droplet Number Rival the First Indirect Effect?, Geoph.Res.Lett, 29 (17), 1848, doi: 10.1029/2002GL015295, 2002. 
Pérez, C., Nickovic, S., Pejanovic, G., Baldasano, J. M., and Özsoy, E.: Interactive dust-radiation modeling: a step to improve weather forecasts, J. Geophys. Res., 111, D16206, doi:10.1029/2005JD006717, 2006.

Pielke, R. A., Cotton, W. R., Walko, R. L., Tremback, C. J., Lyons, W. A., Grasso, L. D., Nicholls, M. E., Moran, M. D., Wesley, D. A., Lee, T. J. and Copeland, J. H.: A comprehensive meteorological modeling system-RAMS, Meteor. Atmos. Phys.,49, 69-91, 1992.

Pierce, J. R. and Adams, P. J.: Global evaluation of CCN formation by direct emission of sea salt and growth of ultrafine sea salt, J. Geophys. Res., 111, D06203, doi:10.1029/2005JD006186, 2006.

Prospero, J. M., Blades, E., Mathison, G., and Naidu, R.: Interhemispheric transport of viable fungi and bacteria from Africa to the Caribbean with soil dust, Aerobiologia, 21(1), 1-19, 2005.

Pruppacher, H. R. and Klett, J. D.: Microphysics of Clouds and Precipitation, Second Revised and Enlarged Edition with an Introduction to Cloud Chemistry and Cloud Electricity, Kluwer Academic Publishers, Dordrecht, 954 pp., 1997.

Querol, X., Pey, J., Pandolfi, M., Alastuey, A., Cusack, M., Perez, N., Moreno, T., Viana, M., Mihalopoulos, N., Kallos, G., Kleanthous, S.: African dust contributions to mean ambient PM10 mass-levels across the Mediterranean Basin, Atmos. Environ., 43(28), 4266-4277, 2009.

Ramanathan, V., Muvva, V., Ramana, G., Roberts, G., Kim, D., Corrigan, C., Chung, C., and Winker, D.: Warming trends in Asia amplified by brown cloud solar absorption, Nature, 448, 575-578, 2007.

Rosenfeld, D., Khain, A., Lynn, B., and Woodley, W. L.: Simulation of hurricane response to suppression of warm rain by sub-micron aerosols, Atmos. Chem. Phys., 7, 3411-3424, doi:10.5194/acp7-3411-2007, 2007.

Rosenfeld, D., Lohmann, U., Raga, G. B., O’Dowd, C. D., Kulmala, M., Fuzzi, S., Reissell, A., and Andreae, M. O.:Flood or Drought: How Do Aerosols Affect Precipitation?, Science, 321(5894), 1309-1313 doi:10.1126/science.1160606, 2008.

Sassen, K., DeMott, P. J., Prospero, J. M., and Poellet, M. R.: Saharan dust storms and indirect aerosol effects on clouds: CRYSTAL-FACE results, Geophys. Res. Lett, 30, 1633, doi:10.1029/2003GL017371, 2003.

Saleeby, S. M. and Cotton, W. R.: A large droplet mode and prognostic number concentration of cloud droplets in the Colorado State University Regional Modeling System (RAMS). Part I: Module descriptions and supercell test simulations, J. Appl. Meteor., 43, 182-195, 2004.

Seifert, A. and Beheng, K. D.: A two-moment cloud microphysics parameterization for mixed-phase clouds. Part II: Maritime vs. continental deep convective storms, Meteorol. Atmos. Phys., 92, 67-82, 2006.

Seinfeld, J. H. and Pandis, S. N.: Atmospheric Chemistry and Physics: From Air Pollution to Climate Change, J. Wiley, Sons, Inc., New York, 1998.

Seinfeld, J. H., Carmichael, G. R., Arimoto, R., Conant, W. C., Brechtel, F. J., Bates, T. S., Cahill, T. A., Clarke, A. D., Doherty, S. J., Flatau, P. J., Huebert, B. J., Kim, J., Markowicz, K. M. ,Quinn, P. K., Russell, L. M., Russell, P. B., Shimizu, A., Shinozuka, Y., Song, C. H., Tang, Y., Uno, I., Vogelmann, A. M., Weber, R. J., Woo, J. H., and Zhang, X. Y.: ACE-ASIA regional climate and Atmospheric chemical effects of Asian dust and pol- lution, B. Am. Meteorol. Soc., 85, 367-380, 2004.

Schulz, M., Balkanski, Y., Guelle, W., and Dulac, F.: Role of aerosol size distribution and source location in a three-dimension simulation of a Saharan dust episode tested against satellitederived optical thickness, J. Geophys. Res.-Atmos., 103, 1057910592, 1998.

Slinn, S. A. and Slinn, W. G. N.: Predictions for particle deposition on natural waters, Atmos. Environ., 14, 1013-1016, 1980.

Smagorinsky, J.: General circulation experiments with the primitive equations, Part I: The basic Experiment, Mon. Weather Rev., 91, 99-164, 1963.

Spyrou, C., Mitsakou, C., Kallos, G., Louka, P., and Vlastou, G.: An improved limited-area model for describing the dust cycle in the atmosphere, J. Geophys. Res., 115, D17211, doi:10.1029/2009JD013682, 2010.

Stevens, B. and Feingold, G.: Untangling aerosol effects on clouds and precipitation in a buffered system, Nature, 461, 607-613, doi:10.1038/nature08281, 2009.

Sun, D., Lau, K. M., Kafatos, M., Boybei, Z., Leptoukh, G., and Yang, C.: A numerical simulation of the impacts of African dust aerosols and associated Saharan air layer on Atlantic tropical cyclone development, J. Climate, 22, 6230-6250, doi:10.1175/2009JCLI27381, 2009.

Teller, A. and Levin, Z.: The effects of aerosols on precipitation and dimensions of subtropical clouds: a sensitivity study using a numerical cloud model, Atmos. Chem. Phys., 6, 67-80, doi:10.5194/acp-6-67-2006, 2006.

Tremback, C. J.: Numerical simulation of a mesoscale convective complex: Model development and numerical results, PhD Diss., Atmos Sci Paper No. 465, Colorado State University, Department of Atmospheric Science, Fort Collins, CO 80523, 1990.

Twomey, S.: The influence of pollution on the short-wave albedo of clouds, J. Atmos. Sci. 34, 1149-1152, 1977.

van den Heever, S. and Cotton, W. R.: Urban aerosol impacts on downwind convective storms, J. Appl. Met., 46, 828-850, 2007.

van den Heever, S. C., Carrio, G. G., Cotton, W. R., DeMott, P. J., and Prenni, A. J.: Impacts of nucleating aerosol on Florida storms: Part I: Mesoscale simulations, J. Atmos. Sci., 63, 1752 1775, 2006.

Walko, R. L., Cotton, W. R., Meyers, M. P., and Harrington, J. Y.: New RAMS cloud microphysics parameterization, Part I: The single-moment scheme, Atmos. Res., 38, 29-62, 1995.

Walko, R. L., Band, L. E., Baron, J., Kittel, T. G. F., Lammers, R., Lee, T. J., Ojima, D., Pielke Sr., R. A., Taylor, C., Tague, C., Tremback, C. J., and Vidale, P. J.:Coupled atmospherebiophysics - hydrology models for environmental modelling, J. Appl. Meteor., 39, 931-944, 2000.

Wesely, M. L.: Parameterization of surface resistances to gaseous dry deposition in regional-scale numerical models, Atmos. Environ., 23, 1293-1304, 1989.

Wurzler, S., Reisin, T. G., and Levin, Z.: Modification of mineral dust particles by cloud processing and subsequent effects on drop size distributions, J. Geophys. Res., 105(D4), 4501-4512, 2000.

Yin, Y., Wurzler, S., Levin, Z., and Reisin, T. G.: Interactions of mineral dust particles and clouds: Effects on precipitation and cloud optical properties, J. Geophys. Res., 107(D23), 4724, doi:10.1029/2001JD001544, 2002.

Yin, Y. and Chen, L.: The effects of heating by transported dust layers on cloud and precipitation: a numerical study, Atmos. Chem. 
Phys., 7, 3497-3505, doi:10.5194/acp-7-3497-2007, 2007.

Yu, S., Saxena, V. K., Wenny, B. N., DeLuisi, J. J., Yue, G. K., and Petropavlovskikh, I. V.: A study of the aerosol radiative properties needed to compute direct aerosol forcing in the south-eastern United States, J. Geophys. Res., 105, 24739-24749, 2000.

Wilcox, E., Lau, K. M., and Kim, K. M.: A northward shift of the Inter-tropical Convergence Zone in response to summertime Saharan dust outbreak, Geophys. Res. Lett., 37, L04804, doi:10.029/2009GL0 41774, 2010.

Wilks, D. S.: Statistical Methods in the Atmospheric Sciences, Academic Press NY, 260-271, 2006.

Zender, C. S., Bian, H., and Newman, D.: Mineral Dust Entrainment and Deposition (DEAD) model: Description and 1990s dust climatology, J. Geophys. Res., 108(D14), 4416, doi:10.1029/2002JD002775, 2003.
Zender, C. S., Miller, R., and Tegen, I.: Quantifying Mineral Dust Mass Budgets: Terminology, Constraints, and Current Estimates, Eos Trans. AGU, 85(48), 509-512, doi:10.1029/2004EO480002, 2004.

Zhang, K. M., Knipping, E. M., Wexler, A. S., Bhave, P. V., and Tonnesen, G. S.: Size distribution of sea-salt emissions as a function of relative humidity, Atmos. Environ., 39, 3373-3379, 2005.

Zhang, H., McFarquhar, G. M., Saleeby, S. M., and Cotton, W. R.: Impacts of Saharan dust as CCN on the evolution of an idealized tropical cyclone, Geophys. Res. Lett., 34, L14812, doi:10.1029/2007GL029876, 2007. 